


\title{
THE CASE OF THE INVISIBLE LITERATURE: POWER, SCHOLARSHIP, AND CONTEMPORARY JAVANESE WRITING*
}

\author{
George Quinn
}

\section{I. "Bukan Makhluk Ciptaan Tuhan?"}

In 1976 an anthology of short stories in the Indonesian language entitled Sebuah Cinta Sekolah Rakyat [A Tale of Puppy Love] by Toti Tjitrawarsita won a major national literary prize, the annual literary award of the Yayasan Buku Utama. ${ }^{1}$ The stories in the collection were translations (with minor modifications) of stories which the author, under the pseudonym Mbak Minuk, had originally published over a number of years in the Javanese-language magazine Jaya Baya. At the time of their appearance in Javanese the stories had been greeted with silence at the national level.

Toti Tjitrawarsita was delighted to receive the prize, but was more than a little bewildered at the contrast in critical reception accorded her work. She felt that the mere act of rewriting her stories in Indonesian could not have transformed her from a writer unworthy of critical attention to one whose talents deserved wide acclaim. If there was any merit in her writing, she remarked, it should not be ignored at the national level simply because she wrote in Javanese. ${ }^{2}$ Toti Tjitrawarsita is by no means the only Javanese author to have expressed misgivings about the attitude of scholars and the national literary establishment towards contemporary Javanese literature. What can be viewed, at the very best, as a kind of double standard seems to be at work. Indeed, as if adding insult to injury, many scholars and critics, both within Indonesia and abroad, have doubted, and even denied, as I shall show presently, the very existence of a significant contemporary literature in Javanese. I purposely use the phrase "insult to injury" because some Javanese writers feel aggrieved at the critical neglect of their work. ${ }^{3}$ A few even

* This article has benefited greatly from comments by Tony Day and Peter Worsley of Sydney University. I wish to record here my warmest thanks for this help. I must add that on certain points I have disagreed with both of the above and only I can take responsibility for the article's present form, with its many weaknesses.

1. See "Para Pemenang Kali Ini," Tempo, Oct. 7, 1978, p. 41. Toti Tjitrawarsita's co-prize winner in 1976 was Iskasiah Sumarto, who also commenced her literary career writing in Javanese.

2. Remark made in an interview with me in Surabaya, Dec. 29, 1981.

3. Javanese writers frequently plead for critics and scholars to take an interest in their work, see, for example, Susilomurti, "Situasi Sastra Jawa," Basis, 16 (Dec. 1966), pp. 69-76; Suripan Sadi Hutomo, "Kritik dan Essay dalam Sastra Jawa Moderen," Sinar Harapan, March 20, 1972; and Soedharma K. D., "Kritikus Tanggon Sastra Jawa Gagrag Anyar," pt. 1, Kunthi, 5, no. 9 [1967], pp. 5-7; pt. 2, ibid., 5 , no. $10[1967], \mathrm{pp} .11-12$. For explicit reference to grievance at critical neglect, 
consider that the professed ignorance of what is so self-evident and substantial a phenomenon as contemporary Javanese literature cannot be interpreted as other than a studied attitude of prejudiced disparagement. Thus, writer and critic Soedharma K.D. protests: "Are [Javanese] writers to be considered beings from another planet, beings who are somehow not true creatures of God?" 4

The purpose of what follows is to examine scholarly attitudes to contemporary Javanese literature and point tentatively to the workings of power and ideology in the shaping of these attitudes. Given that, in the eyes of many observers, Javanese literature has died, or, if it speaks at all, articulates only its own scarcely audible death rattle, I propose first to sketch the quantitative dimensions of contemporary Javanese literature, for it is against the background of a very obvious literary amplitude that the poverty of much scholarly comment becomes all too evident.

The number of novels and novellas to have appeared in Javanese certainly approaches and probably exceeds 500 titles. In his Telaah Kesusastraan Jawa Modern [A Study of Modern Javanese Literature], ${ }^{5}$ Suripan Sadi Hutomo mentions a total of 190 novels or novelistic works published since the turn of the century. His survey is especially valuable for the reference it makes to novels published as serials in magazines since Indonesia's independence. Suripan notes forty-six titles in this category. In the introduction to his Javanese Literature Since Independence, ${ }^{6} \mathrm{~J}$. J. Ras cites over 160 titles of novels or novelistic works. An important feature of Ras' survey is the attention it gives to the preindependence publications of Balai Pustaka, the colonial government publishing house. Ras mentions seventyseven Balai Pustaka novels in this category, and nine more published by Balai Pustaka after independence. The survey Sastra Jawa Modern [Modern Javanese Literature] prepared by the Faculty of Arts and Letters at Gadjah Mada University lists in its appendix a total of 260 titles. ${ }^{7}$ My own collection of Javanese novels and novellas at present numbers more than 300 titles. $^{8}$

see, for example, Bisri Adisoedarmo, "Nalusuri Kasusastran Jawi," Panjebar Semangat, 33, no. 11 (April 4, 1967), pp. 17-18.

4. Soedharma K. D., "Sastra dan Pengarangnya Kurang Darah?" (Paper presented at the Sarasehan Sastra Jawa 1979, Pusat Pengembangan Kebudayaan Jawa Tengah, Solo, May 28-31, 1979), p. 1.

5. Jakarta: Pusat Pembinaan dan Pengembangan Bahasa, Dep. Pendidikan dan Kebudayaan, 1975, pp. 65-66.

6. The Hague: Nijhoff, 1979.

7. Yogyakarta: Fakultas Sastra dan Kebudayaan, Universitas Gadjah Mada, 1976/77.

8. No adequate bibliography of contemporary Javanese literature yet exists. The figures I give here are drawn from surveys, none of which pretends to represent the totality of titles to have appeared in Javanese. My estimate of around 500 titles was reached by collating various surveys and adding on a factor to represent uncited and very recent titles. In 1977 Soedharma K. D. estimated that, on the average, fourteen new novels were published annually; see Soedharma K. D. , "Pangrembakanipun Novel lan Cariyos Cekak Jawi," pt. 1, Mekar Sari, 21, no. 9 (July 1, 1977), pp. 20-21; pt. 2, ibid., 21, no. 10 (July 15, 1977), pp. 18-19. Over the past few years the three principal publishers of fiction, the magazines Panjebar Semangat, Jaya Baya, and Djaka Lodang, have each managed to serialize some three or four new novels a year. 
At the moment there are five large-circulation periodicals appearing regularly in Javanese. They are Panjebar Semangat (Surabaya weekly in magazine format), Jaya Baya (Surabaya weekly in magazine format), Parikesit (Solo weekly in newspaper format), Mekar Sari (in magazine format appearing twice a month in Yogyakarta), and Diaka Lodang (Yogyakarta weekly in magazine format). As of December 1981, Paniebar Semangat claimed a circulation of 63,000, Jaya Baya around 44,000, Djaka Lodang around 20,000, and Mekar Sari around 10,000. ${ }^{9}$ Parikesit probably has sales of around 10,000. In toto, then, the five periodicals have an estimated average weekly sale of around $140,000{ }^{10}$ The readership of Javaneselanguage periodicals is remarkably stable. Unlike Indonesian-language magazines which tend to have an urban-centered readership and consequently a high proportion of casual "off the street" sales, Javanese-language magazines are overwhelmingly distributed, through networks of agents, to subscribers, most of whom live in small towns and rural areas. In some cases, those of Jaya Baya and Panjebar Semangat for example, subscriber sales come close to accounting for the entire output. ${ }^{11}$ Since each copy passes through several hands, it seems to me very likely that the number of Javanese who read at least once a week or fortnight in their own language cannot be less than half a million. If this is true, it seems equally likely that many more people are regularly reading in Javanese today than at any previous time in history.

The five periodicals carry at least one short story and, with the exception of Mekar Sari, one episode of a serialized novel in each issue. The number of new short stories currently appearing annually, then, must be between 200 and 250 . It is impossible to estimate the total corpus of short stories in Javanese, but, bearing in mind that short stories first began appearing in the 1930s in the magazines $\mathrm{Pa}-$ njebar Semangat and Kejawen, it must run to many thousands. Poetry, while not as prominent in magazines as short stories, nevertheless does appear frequently. Mekar Sari runs a regular page of new poetry, edited by Suripan Sadi Hutomo, while Jaya Baya usually features one or two new poems in each issue. Again, the corpus of modern poetry in Javanese must run to many thousands of items. Four substantial anthologies of short stories and poetry have been published, namely

9. Interviews with $W$. Santosa of Panjebar Semangat's editorial staff, Surabaya, Dec. 29, 1981; Sukir Guntaryo of Jaya Baya's administrative staff, Surabaya, Dec. 29, 1981; Soejadi, a writer for Djaka Lodang, Yogyakarta, Jan. 11, 1982 ; Handung Kus Sudyarsana of Mekar Sari's editorial staff, Yogyakarta, Jan. 9, 1982.

10. In addition to this figure, the periodicals also publish special "village editions" [edisi padesan] as part of the government's Newspapers in Villages [Koran Masuk Desa] campaign. But the size of the circulation of these village editions is not clear, since many are not distributed separately but are inserts in their "mother" magazines. There are, moreover, a number of small-circulation literary periodicals in Javanese, most notably Pustaka Candra, a monthly published in Semarang by the provincial government of Central Java under the editorship of Doyosantoso, better known as the poet and critic Muryalelana. This journal is mainly for distribution to educational institutions. Other small-circulation, stencilled journals of a mainly literary character are Baluwarti (Solo), Rara Jonggrang (Yogyakarta), and Kethinthang (Surabaya).

11. According to Mr. Sukir Guntaryo of Jaya Baya, only about 250 copies of the Magazine are sold off the street each week, and Mr. W. Santosa of Panjebar Semangat reports almost no off-the-street sales. In contrast, the number of permanent subscribers to these two magazines may reach a combined total of around 100,000. 
Kumandhang [Resonance] in 1957, ${ }^{12}$ Taman Sari [Garden of Flowers] in $1975,{ }^{13}$ a volume appended to the Sastra Jawa Modern in 1976/1977, ${ }^{14}$ and Ras' Javanese Literature Since Independence. Three slim anthologies of short stories and poems have been issued by the Adijaya Cooperative, Jakarta, under the editorship of Susilomurti, ${ }^{15}$ and an anthology wholly devoted to poetry appeared in 1975 edited by St. Iesmaniasita under the title Geguritan, antologi sajak-sajak Jawi [Poems, an anthology of Javanese verse]. ${ }^{16}$

While modern stage drama does not appear to have developed vigorously in Javanese, radio drama has exhibited an astonishing fertility. Radio plays in Javanese, regularly broadcast by the Yogyakarta station of Radio Republik Indonesia, have always had a large, and at times fanatical, following. ${ }^{17}$ Director and writer Sumardjono is reported to have written (or adapted), and put on the air, some 500 plays since he joined Keluarga Yogya [Yogya Family], a Javanese radio-drama group which commenced broadcasting in Yogyakarta during the Revolution. A similar enthusiasm for radio drama is evident in Jakarta, where up to a dozen private radio stations have regularly broadcast plays in Javanese. The Jakarta station of Radio Republik Indonesia has also broadcast plays in Javanese, most written and produced by Guritno. Like Yogyakarta's Sumardjono, Guritno is reputed to have prepared and put on the air some 500 scripts. In Solo, Lucia Siti Aminah Subanto claims to have written some 400 plays in Javanese and broadcast them over the local station of Radio Republik Indonesia. ${ }^{18}$

Yet the quantitative magnitude of contemporary Javanese literature has failed to spark a commensurate measure of interest from scholars, whether Indonesian or foreign. Neither of the two comprehensive surveys of Javanese literature which have appeared to date, Poerbatjaraka's Kapustakan Jawi [Javanese Literature] (1952),

12. Ed. Senggono (Jakarta: Balai Pustaka, 1957).

13. Published by the Pusat Kebudayaan Jawa Tengah [Central Java Cultural Center], Sasanamulya Baluwarti, Surakarta, for the Convention of Javanese Writers, March 23-25, 1975.

14. See above n. 7 .

15. The three anthologies are entitled Langite Isih Biru [The Sky is Still Blue], 1975, Dongeng Katresnan [Love Story], n.d., and Langit Jakarta [Jakarta Sky], $\mathrm{n} . \mathrm{d}$. , all issued in a series entitled Kumpulan Cerkak Pilihan [Anthology of Selected Short Stories].

16. Surakarta: Pustaka Sasanamulya, 1975. A number of smaller, mostly stencilled, anthologies of poetry have appeared, for example Tepungan Karo Omah Lawas: Kumpulan Puisi Jawa Lima Penyair Blora [Returning to My Old House: An Anthology of Javanese Poetry by Five Poets from Blora] (Surakarta: Pusat Kebudayaan Jawa Tengah, 1979).

17. See S. N. Ratmana, "Sandiwara Radio Bahasa Daerah RRI Yogyakarta Kegiatan Budaya Yang Perlu Digalakkan," Kompas, Feb. 25, 1975, p. 5. See also, "Satu Tanah Air, Satu Bangsa, Berapa Bahasa," Tempo, Oct. 18, 1975, pp. 51-52. Innovative forms of traditional drama such as kethoprak and ludrug have, of course, flourished, and these forms have had considerable bearing on the character of popular prose narrative, the so-called panglipur wuyung novellas.

18. See "Cerita di Larut Malam," Tempo, Sept. 30, 1978, p. 26; "Sandiwara Jawa ing Radio2 Jakarta: Gragapan Naskah lan Pemain," Kumandang, 5, no. 208 (1978), p. 4; and "Ibu Lucia Siti Aminah Subanto Pangripta Sandiwara Radio RRI Surakarta," Panjebar Semangat, March 19, 1983, p. 35. 
and Pigeaud's Literature of Java (1967), attempts to discuss twentieth century developments in the field. Poerbatjaraka offers no excuse for the omission. Pigeaud recognizes the existence of contemporary writing in Javanese, but, the title of his book notwithstanding, he says that "the present Synopsis of Javanese literature up to about 1900 is not the place to discuss modern developments at any length." 19 Pigeaud provides a select bibliography of books and treatises on Javanese literature, but, of the 121 items cited, only one might conceivably be regarded as directly relevant to contemporary writing. ${ }^{20}$ E. M. Uhlenbeck's $A$ Critical Survey of Studies on the Languages of Java and Madura (1964), cites a few works which fall within the ambit of contemporary Javanese literature, but his primary focus of attention is the more distant past. He does not justify this orientation, but in his introduction merely says:

Within the last century, but especially since the founding of Bale Pustaka (1908) hundreds of books written in Sundanese and Javanese have been published. No useful purpose is served in trying to include them all in this bibliography. ${ }^{21}$

Nor does contemporary Javanese literature receive more than token attention in Indonesian universities. A glance at the list of theses and academic exercises written on regional languages and literatures in the Faculty of Arts at the University of Indonesia (where there is a Department of Javanese Literature) between 1952 and 1970 reveals that of the sixty-three items mentioned, not one bears directly on contemporary Javanese writing. ${ }^{22}$ A survey of theses written in the Department of Javanese Literature at the State Teacher Training University of Yogyakarta [IKIP Negeri Yogyakarta] and in the Department of Regional Literatures [Jurusan Sastra Nusantara] in the Faculty of Arts and Letters at Gadjah Mada University in Yogyakarta shows that of forty-seven theses listed only seven relate directly to contemporary Javanese writing. ${ }^{23}$

Luckily, the situation is not unrelievedly gloomy. There is a relatively large amount of critical commentary, predominantly in the Javanese language, mostly in the form of conference [sarasehan] papers and magazine articles. ${ }^{24}$ During the 1970 s a few tentative overviews of contemporary Javanese literature appeared. The first was Suripan Sadi Hutomo's Indonesian-language Telaah Kesusastraan Jawa Modern, where he discusses poetry, short stories, and novels, and adds short chapters on roman panglipur wuyung [popular novels] and sastra keagamaan [religious literature]. Ras' introduction to his Javanese Literature Since Independence is a brief but thorough survey, concentrating on prose fiction. Possibly the best,

19. Th. G. Th. Pigeaud, Literature of Java, 1 (The Hague: Nijhoff, 1967), p. 9.

20. This work is Pratelan Kawontenaning Buku-Buku ing Gedhong Buku Museum ing Batawi [A Survey of Books in the Library of the Batavia Museum] by Poerwasoewignja and Wirawangsa (Batavia, 1921).

21. E. M. Uhlenbeck, A Critical Survey of Studies on the Languages of Java and Madura (The Hague: Nijhoff, 1964), p. 3.

22. See Bibliografi Skripsi Universitas Indonesia (Jakarta: Universitas Indonesia, 1979), pp. 6-11.

23. Inventarisasi Karangan Berharga Tentang Sastra Jawa Modern (Yogyakarta: FKSS IKIP Negeri, 1977/78), p. 27.

24. An interesting initial attempt to explore this body of commentary is to be found in the voluminous Yogyakarta Inventarisasi (see above note). The appendix to this survey reprints many of what the editors consider the most significant articles. 
certainly the most comprehensive, discussion of contemporary Javanese literature to have appeared so far is Gadjah Mada University's Sastra Jawa Modern, which encompasses separate discussions of novels, short stories, and poetry, divides the discussion of each genre into credibly argued historical periods, and exhibits broadranging familiarity with the works it surveys. ${ }^{25}$

The field of Javanese literature as a whole is a broad and diverse one, confronting the student with formidable problems of access and methodology. The field is still underexplored, and, in large areas, unexplored, while scholars working in it are few. Under the circumstances, is it not forgivable, or at the very least understandable, that an important portion of it relating to developments in the twentieth century has been, at least until very recently, so conspicuously neglected? What I want to argue here (and I feel that, regrettably, in the field of Indonesian literary studies it still needs to be argued) is that "unevenness" (read: neglect, omission, and uninformed disparagement) is never innocent. The choices we make as scholars spring from the ideologies which govern our thinking. The neglect of contemporary Javanese literature has been neither fortuitous, unavoidable, nor innocent, but has stemmed from a variety of imperatives to which we need to pay attention. In my opinion, three main ideological complexes have acted upon scholars, critics, and observers who have failed to see contemporary Javanese literature or whose remarks about it have been dismissive, namely the ideologies of European imperialism, of conservative priyayi hegemony, and of Indonesian nationalism. In the sections that follow I shall examine each of these in turn.

\section{II. "Heel weinig literatuur van eenige beteekenis"}

It is my purpose in this section to describe a tradition, a short one no doubt, and a meager one, but, nevertheless, a tradition, with all the coherence, self-sustaining momentum and, above all, cumulative authority that defines a tradition. It is the tradition of European (in effect Dutch) critical comment on contemporary Javanese literature, which, with the lonely and enlightened exception of Ras, appears to have caught in its embrace all the European scholars and not a few Indonesians who have turned their attention to the field. ${ }^{26}$ The origins of the tradition in the 1920s and 1930s are clear, consisting of some five articles which appeared in authoritative publications of the time.

Two of these articles are "omissive" in character, that is, while inviting the supposition that they might have something to say about contemporary Javanese literature, they make virtually no reference to its existence. The first of these is the anonymous entry in the Encyclopaedie van Nederlandsch-Indië under "Literatuur (Javaansche)." The article is in two parts, the first appearing in the 1921 impression of the Encyclopaedie, and the second in the supplementary eighth part published

25. See above, n. 7. This Gadjah Mada study was commissioned by the Department of Education and Culture of the Special Region of Yogyakarta. It was classified until such time as its findings could be discussed and collated with other research. To my knowledge, it is still not freely available to the public.

26. One figure who preceded the rise of this tradition and whose views were antithetical to it was G. A. J. Hazeu. In his inaugural address as professor at Leiden University in 1921, Hazeu expressed confidence in the continuing vitality of Javanese literature and Javanese culture in general, and he commented favorably on the newly published novel Serat Riyanta by Sulardi, which today is often referred to as the very first "true" novel in Javanese; see G. A. J. Hazeu, Oud en Nieuw uit de Javaansche Letterkunde (Leiden: Brill, 1921), pp. 23-26. 
in 1939. 27 The first of the two parts displays incomparably more interest in contemporary developments, but, because it was written prior to the substantive rise of modern poetry and prose fiction in the $1920 \mathrm{~s}$ and $1930 \mathrm{~s}$, it is scarcely relevant here. Contrary to what one might expect, the second part, intended to complement the first and published some twenty years later, talks about general issues relating to the field, but makes no mention at all of developments in Javanese literature itself during this intervening period. In short, a reader of the Encyclopaedie's article on Javanese literature would not suspect that the 1920s and 1930s had witnessed the birth of a wholly new style of writing.

The other article, "Volkslectuur in 1930" by G. W. J. Drewes, first appeared in the newspaper De Locomotief and was later reprinted in the prestigious journal Diawa. ${ }^{28}$ Surveying the Indonesian literary scene in general, Drewes comes to the gloomy conclusion that,

There is perhaps but little literature of any significance in prospect, for the time of transition in which we live is scarcely conducive to the full flowering of literary gifts and poetic talents. ${ }^{29}$

Turning to specifically Javanese publications, Drewes notes that in 1930 the government publishing house, Balai Pustaka, published thirty new titles, but, although he observes that among them there were wayang stories and a Javanese adaptation of the European tale Luilekkerland [Land of the Lotus-eaters], he does not mention that at least four novels had appeared during the year, including the striking $A y u$ Ingkang Siyal [Misfortune Brought by Beauty] by Sugeng Tjakrasuwignja and Maryati lan Maryana [Maryati and Maryana] by Siswamihardja. ${ }^{30}$

The three other articles, all of which were published in 1932, are "dismissive" in character, that is, while discussing contemporary Javanese literature, they have little that is complimentary or constructive to say about it. Two of the articles appeared in Djawa. In the first of them, entitled "Over de Beoefening der Javaansche Letterkunde in de Laatste Veertig Jaren" [On the Development of Javanese Literature over the Last Forty Years], 31 Pigeaud postulates the existence of two streams in recent Javanese writing--the traditionalist stream, following in the footsteps of Raden Ngabei Ranggawarsita, and the modernist stream, indebted to the forms of contemporary European writing. On works in the modernist stream Pigeaud comments,

. . from the point of view of their literary merit, which is not very great, these works have so far failed to reform Javanese literature, and they cannot be regarded as a factor of any importance in the social and literary renewal of the Javanese. ${ }^{32}$

27. (The Hague: Nijhoff, 1921/1939). The 1921 edition was edited by D. G. Stibbe, and that of 1939 by D. G. Stibbe and F. J. W. H. Sandbergen.

28. De Locomotief, Dec. 19, 1930; and Diawa, 10 (1930), pp. 234-38.

29. This and all subsequent translations in this article are the present writer's.

30. In 1946 Drewes published an anthology of contemporary Javanese writing which included extracts from novels. The anthology appears to have been assembled hastily, for it has no introduction and a number of important prewar novels are unrepresented. See G. W. J. Drewes, Eenvoudig Hedendaagsch Javaansch Proza (Leiden: Brill, 1946).

31. Djawa, 12 (1932), pp. 4-7.

32. Ibid., p. 6 . 
In the second of the Diawa articles, headed "Javaansche Uitgaven van Volkslectuur" [Javanese Books Published by the Bureau for Popular Literature], ${ }^{33} \mathrm{C}$. Hooykaas summarizes seven novels published by Balai Pustaka over the previous two and a half years. Hooykaas berates Javanese authors for submitting dozens, indeed hundreds, of manuscripts which, he says,

. . are mere assemblages of more or less likely incidents, mostly of no interest whatever, marked by unlifelike characters who remain no more than names or ciphers and whose motives and circumstances are hazy, so that all too often [these works] can be characterized as nothing other than overblown school exercises. ${ }^{34}$

Hooykaas scarcely bothers to conceal his disdain, if not outright contempt, for those Javanese attempting the difficult task of writing in contravention of their traditional literary norms. He declares,

Most Balai Pustaka writers of Javanese books are employed in education, and for the most part they take up the pen to write a novel for Balai Pustaka with the same fire and talent that they would put into an account of a bicycle tour; the expectation of payment does not lend wings to their sandals. ${ }^{35}$

In the third of these articles, Drewes, writing in De Gids, reiterates his view that it is useless to expect good literature in a time of transition in which European literary norms are still in the process of being assimilated. ${ }^{36}$ He says that, although quite a few new prose works in Javanese have been published, there is not much to say about them. None of the recently published domestic romances, which he describes as being woven out of partings, miraculous reunions, and all that can occur in between, have, up to 1930 , achieved the same popularity as wayang-type stories, and he criticizes them for being innovative only in taking as their setting the everyday, domestic environment. ${ }^{37}$

An early figure in the dismissive tradition to which the triumvirate of Pigeaud, Hooykaas, and Drewes gave birth was Professor J. Gonda. In 1947 he published an anthology of Indonesian literature entitled Letterkunde van de Indische Archipel [Literature of the Indian Archipelago]. His long introduction includes some comments on contemporary Javanese literature which are taken almost verbatim from Pigeaud's article in Djawa. ${ }^{38}$ He also mentions the novel Dwikarsa by Sastraatmadja, the only title he mentions, and the writer Asmawinangun. Both of these references appear to be drawn from Hooykaas' article, while his comments that the Malays, less supported than the Javanese by their own high culture, are more receptive to translations from European languages, is also a clear echo of Hooykaas' opinion. ${ }^{39}$

33. Ibid., pp. 93-115.

34. Ibid., p. 111.

35. Ibid.

36. G. W. J. Drewes, "Oud en Nieuw in de Hedendaagsche Indonesische Litteratuur," De Gids (1932), 3, pp. 316-36, at p. 325 .

37. Ibid., pp. 333-34.

38. J. Gonda, Letterkunde van de Indische Archipel (Amsterdam/Brussels: Elsevier, 1947), p. 45. Gonda does not acknowledge his use of Pigeaud's article nor mention it in his bibliography, but the resemblance to Pigeaud's remarks ( $p$. 6) makes the debt unmistakable.

39. Cf. Hooykaas, "Javaansche Uitgaven," pp. 111 and 114. 
In a 1953 article, entitled "Eb en Vloed aan Java's Literatuurstrand" [Ebb and Flow on Java's Literary Shores], R. Slamet Roosman asserts that, as far as recent Javanese literature is concerned, "er word zo goed als niets geproduceerd" [virtually nothing has been produced] ${ }^{40}$ while in his Modern Indonesian Literature, Professor A. Teeuw declares that, "neither in quantity nor quality did these modern Javanese and Sundanese works come anywhere near modern Malay-Indonesian literature" and that "really modern literature in Javanese is negligible in comparison with that in Malay." 41

In his Modern Javanese Historical Tradition (1978), Professor M. C. Ricklefs concludes his survey of the supposed decline of Javanese literature thus:

The vitality which had inspired the older literature seems gradually to have been lost, and Javanese hardly produced a truly modern literature. A few modern novels were attempted, but found little success. In the present century, the Dutch colonial government's publishing house "Volkslectuur" (Balai Pustaka) could hardly find a Javanese novel to publish, and those that did appear were unimpressive by the standards of Indonesian novels. Javanese poetry which can be called "modern" is small in quantity and of poor quality. As a result, the twentieth-century national and social issues which might have been expressed in Javanese were instead dealt with in novels and poems written in Indonesian. ${ }^{42}$

It is a striking testimony to the strength of the tradition that, in formulating this opinion, Ricklefs refers not to any personal reading of contemporary Javanese literature, but to Hooykaas' article in Diawa, the first volume of Pigeaud's Literature of Java, and the passage in Teeuw's Modern Indonesian Literature, part of which is cited above. ${ }^{43}$

In essence, Dutch scholars and those who have followed in their footsteps, have been interested in a kind of asocial literary evolution, charting the changes over time within particular genres, postulating developmental periods, seeking out golden ages against which to measure preceding and succeeding phenomena, in short, studying Javanese literature in a fundamentally diachronic fashion and tending to ignore the synchronic perspective that might explain why, in a particular time, the totality of Javanese literary life assumed a particular form. One symptom of this perspective is the almost universally accepted orthodoxy that Javanese literature (indeed some say the whole fabric of Javanese culture) today is in decline.

The notion of decline in Javanese literary life, so very evident in the examples of scholarly comment I have given, is generally defined philologically rather than sociologically. Philologically oriented notions of decline revolve around two principal suppositions, namely that there was once a germinal period of literary brilliance, and that this flowering established a dominant genre embodying immutable literary

40. This article which originally appeared in the journal Minerva was reprinted by Prent en Boek (Amsterdam, 1953), p. 108.

41. 2 vols. (The Hague: Nijhoff, 1979), 1, pp. 75-76.

42. M. C. Ricklefs, Modern Javanese Historical Tradition (London: School of Oriental and African Studies, 1978), p. 221. Ricklefs' assertion (not sourced) that Balai Pustaka could hardly find a Javanese novel to publish is absurd. Ras cited eightysix Balai Pustaka titles, and at least one observer claims that for each manuscript published a dozen were rejected; see Hooykaas, "Javaansche Uitgaven," pp. 113-14; and Ki Sastrawirya, "Mawas Bab Mekaring Basa Jawa Sajeroning $30 \mathrm{Th}$. Seprene" (11 pts.), Mekar Sari, 3, nos. 9-20 (July 1-Dec. 15, 1959), p. 19.

43. Ricklefs, Modern Javanese Historical Tradition, p. 221, n. 54. 
norms. Thus Ricklefs, describing the "decline" of Javanese literature, can say,

If the literary world of the later eighteenth and nineteenth centuries was one in which a classical heritage was being lost and the vernacular alone survived, this would not seem to be a time of "renaissance." 44

The loss of the "classical heritage" (accepting that in fact it did occur) seems to be taken as evidence of general literary decline, and the continuing vitality of a different stream--the "vernacular literature" mentioned by Ricklefs--is, by virtue of its distinctness from the classical heritage, put aside as a significant factor in Javanese literary life. ${ }^{45}$ The problematic notion of decline appears in different guise in the frequent use of the word "transition." Drewes can excuse the perceived immaturity of Javanese writing between the wars as the regrettable, but inevitable, consequence of a time of transition, implying thereby a time of "normality" in the past and the prospect of a return to literary normality at some time (unspecified and unguaranteed) in the future. ${ }^{46}$

As one might expect of a tradition born at a time when European cultural superiority was taken for granted, a hierarchy of cultures topped by that of Europe is implicit in the body of critical comment I have surveyed. It is expressed most pervasively in the emphasis on the derivative character of Javanese literature, and contemporary literature in particular. In volume 1 of his Literature of Java, Pigeaud includes a very short section headed "Novellistic Literature." In the space of a few paragraphs he manages to insist three times on the paternalistic and seminally important role of Dutch scholars in, as it were, "forcing" the Javanese to start writing novelistic works.

. . more and more Javanese authors followed the advice of Dutch scholars to write belletristic novellistic books. . . ( $p .262)$

.. equally on the suggestion of Dutch scholars and officials were

written the remarkable travels of Soma Reja. . . . (p. 262)

. - Javanese authors were encouraged by Dutch scholars to try their

hands at writing prose tales and essays. . . (p. 263)

Having, it seems, browbeaten the reluctant Javanese into writing what Hooykaas calls "this unasked for Western product," ${ }^{47}$ Dutch scholars then proceed to

44. Ibid., p. 217.

45. See J. A. Day's "Review" of Ricklefs' Modern Javanese Historical Tradition in Journal of South East Asian Studies, 11, no. 2 (1980), pp. 442-43, for cogent criticism of Ricklets' extrapolation of general literary decline from the evidence of one minor genre, the Babad Sangkala texts. The demands of the "decline" imperative force Ricklefs into a distorted view of developments in the twentieth century. In addition to claiming that "Javanese hardly produced a modern literature," he asserts, for example, that Budi Utomo "significantly chose to use Indonesian (then still called Malay) rather than Javanese as the common language for its meetings and publications." In fact, Budi Utomo's newspaper Darmo Kondo appeared in both Malay and Javanese editions, and the Budi Utomo press published books in Javanese, including an early masterpiece of contemporary prose fiction, Padmasusastra's Rangsang Tuban, which appeared in 1913. Moreover, although Budi Utomo was strongly Javanese in character, it had supra-Javanese aspirations, so the use of Malay in meetings was sensible rather than evidence of linguistic, still less literary, decline.

46. Drewes, "Volkslectuur in $1930, "$ p. 235.

47. Hooykaas, "Javaansche Uitgaven," p. 111. 
apply to the judgment of these works the criteria employed in conventional European literary criticism of the time. Predictably (but reassuringly no doubt), Javanese novels are weighed in the balance and found terribly wanting. Hooykaas' solution to the problem of the miserable quality of Javanese novels is likewise predictable.

In the meantime, it is not superfluous to continue to provide Western models, which is why Alleen op de Wereld is appearing at the moment in an eight part translation by $M$. Hardjawiraga under the title Badan Sapata. ${ }^{48}$

The case of Badan Sapata presents an interesting illustration of the difficulty Dutch observers had in evaluating the Javanese processing of European stories and literary genres in anything but European literary terms. Alleen op de Wereld was the Dutch translation of French author Hector Malot's famed novel for children Sans Famille [Without Family], published in 1878. In Indonesia the story was translated into several languages and became popular with adults. ${ }^{49}$ Sans Famille relates the adventures of a foundling who, when picked up as a baby on the streets of Paris, is wearing clothes of good quality, suggesting that he is of aristocratic background. As the boy grows up, he has a variety of memorable and essentially unconnected adventures which, in picaresque style, take him all over France and to England. Without setting forth the novel's contents at length, suffice it to say that it is replete with motifs found, in one form or another, in many popular works of traditional Javanese literature. Even the few words of outline given above indicate this; but the same scholars who solemnly analyzed traditional picaresque romances in Javanese could not see Badan Sapata as other than a badly constructed European novel. Discussing Badan Sapata and another long novel, Setya Raja, adapted from Chinese sources, Hooykaas criticized them as being mere "chains of numerous breathtaking episodes without any inner coherence and almost completely disconnected one from the other." But in the following sentence he reported with satisfaction that "an edition of the beloved Menak romance is now in preparation." 50 "The interminably long Menak story is, of course, the picaresque, fragmented, episodic romance par excellence of traditional Javanese literature.

One searches in vain within this scholarly tradition for any glimmer of awareness that contemporary Javanese literature might possess its own aesthetic norms, different from those of other literatures, and indeed different from those applying to Javanese literature of previous ages. Virtually without exception, scholars have hit contemporary Javanese writing with the stamp of triviality or poor quality on the basis of criteria (where any criteria at all have been mentioned) extrinsic to the body of literature on which they are commenting. They give almost no evidence of wide personal familiarity with recent writing, still less of any effort to understand what values might be operating in it. This application of extrinsic criteria is exemplified most clearly in their evaluation of Javanese novels by comparing them with those written in Indonesian. Repeatedly Dutch scholars and their followers have asserted

48. Ibid.

49. An Indonesian translation, entitled Sebatang Kara, was published by Balai Pustaka, and Pustaka Jaya recently issued a new abridged translation under the title Sendiri di Dunia. Indonesian novelist Achdiat Karta Mihardja, who at the commencement of his career wrote in Sundanese, was impressed by Sebatang Kara; see Boen Sri Oemarjati, Roman Atheis, Satu Pembicaraan(Jakarta: Gunung Agung, 1962), p. 17.

50. Hooykaas, "Javaansche Uitgaven," p. 111. 
that Javanese novels are poor by comparison with Indonesian ones, ${ }^{51}$ but I have yet to encounter a single instance of a comparative study which attempts, rigorously or otherwise, to justify this.

It is not easy to see why Indonesian literature, written in the language of the nationalist movement, should have found greater favor with Dutch scholars. Possibly many saw Indonesian as a more "modern" language, strongly influenced by, and closer to, the linguistic and intellectual norms embodied in European languages and therefore more capable of being the vehicle of a "properly" modern (that is ersatz European) literature. As late as 1950 , Professor A. A. Fokker could assert that Indonesia's regional languages were essentially emotive in nature, while Indonesian was essentially intellectual. The elementary state of sociolinguistics at the time scarcely excuses the tautological fatuity of Folkker's conclusions concerning the different quality of Indonesian and the regional languages:

It is quite beyond denial that Indonesian is chiefly intellectual in character, and this brings me to a conclusion of great importance. I have said that the regional languages embrace family life and life in village communities, whereas Indonesian dominates the higher levels of social life. A linguistic analysis of the two language categories reveals that their respective positions in society are clearly reflected in their linguistic characteristics. ${ }^{52}$

The view that Javanese is a basically nonintellectual language (and that, by implication, the users of the language are people governed by passion rather than intellect) has a long history. As Anthony Day points out, it was probably first proposed by John Crawfurd in his History of the Indian Archipelago (1820) and can be traced back to nineteenth century philological views on what were referred to as "inorganic" Asian languages. ${ }^{53}$ This stereotyped image of the Javanese people and their language is implicit in some of the comment on their contemporary literature and may account for the notion that contemporary prose fiction lacks intellectual weight. Take Gonda's comments on Sastraatmadja's novel Dwikarsa, for example. Dwikarsa paints a hair-raising portrait of a Javanese ménage-à-trois. The protagonist of the title, Dwikarsa, takes a second wife and heartlessly pushes his first wife off to an outbuilding. Both Dwikarsa and his new wife belittle and mistreat the first wife, but when, as a consequence of the second wife's idleness and extravagance, they fall on hard times, the second wife comes to the first wife begging for money. Having obtained the money they need, the unsavory pair abandon the first wife and make off to a new life in the desa. For Gonda the novel is apparently thematically and intellectually significant only in that it "brings out the typically Javanese mentality and Javanese condition." 54

51. See, for example, ibid., p. 114 ; Pigeaud, Literature of Java, 1, p. 263 ; Teeuw, Modern Indonesian Literature, pp. 75-76; Ricklefs, Modern Javanese Historical Tradition, p. 221; and Ben Anderson, "Sembah-Sumpah: The Politics of Language and Javanese Culture" (Paper submitted for the Conference on Multilingualism in Modern Indonesia, Pacet [West Java], Aug. 1981), p. 2.

52. A. A. Fokker, Bahasa Indonesia dan Bahasa Daerah (Groningen/Jakarta: Wolters, 1951), p. 13 .

53. J. A. Day, "Meanings of Change in the Poetry of Nineteenth Century Java" (Ph.D. dissertation, Cornell University, 1981), pp. 29-32.

54. Gonda, Letterkunde, p. 45. A summary of this story is given by Hooykaas ("Javaansche Uitgaven," p. 112), and it is to this summary that Gonda evidently refers, rather than to a personal reading of the novel. 
Another reason why Dutch scholars have been able to look with some equanimity on prose fiction in Indonesian, while savaging the genre in Javanese, is that the Malay tradition is perceived as lacking poetic works in the same volume and with the same status as the Javanese literary tradition. Novels are more congenial to the Malays, says Hooykaas, echoed by Gonda, because the Javanese have

. . such a glorious literary tradition, and can still draw upon so many masterpieces within it, that they as yet feel no need of an unasked-for Western product, but the Malays are so much the poorer than the Javanese in this respect that they eagerly accept the new. ${ }^{55}$

In European philological studies of Javanese literature it is almost axiomatic that verse is superior to prose. In fact, prose often seems to be looked on as somehow anomalous. In the field of belles-lettres especially, verse is invariably regarded as dominant, and the perceived decline of Javanese literature is in effect the decline of poetic expression. ${ }^{56}$ In his study of the Babad Sangkala manuscripts Ricklefs says:

There is little doubt that verse was the superior form of Javanese literature. The changing of the babad sangkala genre from verse to prose, and the concomitant loss of facility with chronograms, seem clearly to represent a decline by Javanese standards. 57

In his 1932 survey of Balai Pustaka novels, Hooykaas also suggests that the reason for the execrable quality of Javanese fiction is to be found in the abandonment of poetic forms. Hooykaas concludes that:

. . . it may be easier for the Westerner to force his laws and philosophy into tembang poetry, than for the Oriental to bring his thoughts to clear, comprehensible expression in prose. ${ }^{58}$

The point needs to be made here, and made firmly, considering the emphasis on verse in the study of Javanese literature, that Javanese literature boasts a body of prose works which, while no doubt smaller in quantity than poetic works, is nevertheless a distinct tradition, with its own long and checkered history and its own aesthetic norms. In his Kalangwan Professor Zoetmulder argues convincingly against the use of the terms "kakawin language" and "kidung language" to denote Old Javanese and Middle Javanese.

. . there is Old Javanese prose besides kakawin poetry; while there are also a few (though not very many) prose works that show all or most of the peculiarities which characterize the language of the kidungs. To replace the term "Middle-Javanese" with "kidung language" would therefore be, to say the least, incorrect and confusing. ${ }^{59}$

The post-Islamic literature of the pasisir can also display a number of prose works, ${ }^{60}$

55. Ibid., p. 111, and Gonda, Letterkunde, p. 44.

56. For reference to this view see Day, "Meanings of Change," p. 33 and passim.

57. Ricklefs, Modern Javanese Historical Tradition, p. 212.

58. Hooykaas, "Javaansche Uitgaven," p. 115.

59. P. J. Zoetmulder, Kalangwan: A Survey of Old Javanese Literature (The Hague: Nijhoff, 1974), p. 26.

60. Most of them classified as books of notes (primbon) in Pigeaud's compendium (Pigeaud, Literature of Java). But, as Drewes' edition of one of these works 
while nineteenth century Central Java produced prose pakem wayang and prose histories. ${ }^{61}$

The notion that prose literature was never belletristic in character does not stand up to examination. ${ }^{62}$ Zoetmulder's observations on Old Javanese and Middle Javanese prose works suggest they were belletristic, but in a radically different way from kakawin and kidung poetry. Discussing the Old Javanese parwa he says,

The parwa authors generally succeeded in doing what was expected of them, and their works deserve a place in the history of literature as examples of a type of narrative prose of which the principal assets are simplicity and lucidity. Although they may at times seem a little too plain for our taste, they generally know how to tell a story vividly and fluently, using their language with ease. ${ }^{63}$

Zoetmulder remarks that some Old Javanese prose works "may be presumed to have undergone the impact, or even to have been the written expression, of the more popular forms of speech." 64 Gonda sees in Old Javanese prose a simple style, full of authority, as in the speech of a guru to his pupils, ${ }^{65}$ and in the later pakem the influence of the formal, but immediately intelligible and moving, idiom of the dhalang's narrative is very evident.

In this light, the insinuation that prose literature is in some sense anomalous or aesthetically insignificant is clearly mistaken. Prose literature has been a minor, but consistently present category of Javanese belletristic expression, aesthetically, and to an extent functionally, distinct from poetic literature. When Raden Ngabei Ranggawarsita wrote his long prose "history" of Java's mythical past, Pustakaraja, he was not necessarily being innovative or responding to the influence of Western scholarship, but may, on the contrary, have been proposing a new conservatism, looking back beyond the many verse histories of the eighteenth and nineteenth centuries to an older model, such as is represented in the prose narratives of the Adiparwa, the Pararaton, and the Tantu Panggelaran. ${ }^{66}$ And contemporary prose fiction, while very strongly influenced by European literary norms, is clearly far from

shows, they were far from devoid of clearly belletristic features; see G. W. J. Drewes, The Admonitions of Seh Bari (The Hague: Nijhoff, 1969).

61. See Pigeaud, Literature of Java.

62. Pigeaud (ibid., p. 14) and Ricklefs (Modern Javanese Historical Tradition, p. 208) among others make this claim, though Pigeaud excepts pakem and novelistic works.

63. Zoetmulder, Kalangwan, p. 89. See also Day, "Meanings of Change," pp. 6364 for remarks on the aesthetics of Old Javanese prose.

64. Zoetmulder, Kalangwan, p. 35. See also pp. 88-89.

65. Gonda, Letterkunde, p. 128.

66. Day, "Meanings of Change," p. 187, observes that the prose medium adopted by Ranggawarsita in his famed histories apparently did not repel early readers of the works. No less a figure than the poet-prince Mangkunegara IV thought the histories were ancient and authentic records of Java's early history. Drewes suggests that Ranggawarsita saw his prose histories as a "super Serat Kanda in prose," presenting "a continuous account of Javanese history from its very beginning until modern times," supplementing and complementing verse histories. See G. W. J. Drewes, "Ranggawarsita, the Pustaka Raja Madya and the Wayang Madya," Oriens Extremus, 21, no. 2 (Dec. 1974), p. 215. 
being an alien graft. It is equally inappropriate to suggest, as several scholars do, that the conventions of poetic literature somehow monopolize the embodiment of "Javaneseness" and that the recent contraction of interest in tembang macapat is indicative of a deep, perhaps mortal, crisis in Javanese culture. ${ }^{67}$

Two main questions arise from the foregoing, to which, the reader will guess, I believe the answers are all too clear. First, are we justified in judging one category (prose) by the norms of another (verse)--that is, of saying in effect that verse is aesthetically superior to prose because prose is not verse? Second, are we justified in linking the literary, indeed cultural, vitality of a people with the social fortunes and literary evolution of one particular category or idiom, however dominant it may at one time have been?

Edward Said describes Orientalist scholarship as "a system for citing works and authors." 68 If one thing is clear from the sketch I have given of European views of contemporary Javanese literature, it is that most commentators have preferred to cite the opinions of other scholars, rather than embark on a course of personal acquantaince with the object of their remarks. In this process, not, of course, an exceptional nor in itself a necessarily reprehensible one, the salient norm has been the academic authority of the scholar or publication, rather than clear evidence in the cited source of rigor and wide familiarity with contemporary writing. Thus the "lacuna" in European studies of contemporary Javanese writing is partly a consequence of deference to the authority of a scholastic tradition, and partly the consequence of an a priori rejection of any noteworthy significance in contemporary Javanese writing--these being, of course, two sides of the same coin.

In 1938, philologist, anthropologist, and Director of Balai Pustaka K. A. H. Hidding wrote:

. . . in the still rather primitive Oriental community, which is constituted on lines so entirely different from those in the West, there is as yet no place for the private publisher. ${ }^{69}$

The justification of foreign control and monopoly by pointing to the backwardness of the indigenes was (and still is) one of the principal moral props in the edifice of imperialism. It did not matter to Hidding that, when he wrote these lines, private publishing in the hands of "primitive Orientals" was flourishing in the Netherlands Indies, and had in fact existed for at least fifty years. Evidently, the imperative of the "white man's burden" impelled him to reject the fact of independent enterprise and creativity among Indonesians. For Hidding, literary creativity had to be defined and controlled by Dutch colonial power of which Orientalist scholarship was a crucial component.

Hidding went on:

The novels submitted [to Balai Pustaka] are subjected to the criticism and correction of an editorial board, the members of which have undergone several years of training under thoroughly schooled Orientalists. ${ }^{70}$

67. See especially Ricklefs, Modern Javanese Historical Tradition, p. 220. Pigeaud, Literature of Java, 1, p. 171, can describe nineteenth and twentieth century prose biographies as "alien to the spirit of Javanese literature."

68. Edward W. Said, Orientalism (London: Routledge, 1978), p. 23.

69. K. A. H. Hidding, "The Bureau of Popular Literature," Bulletin of the Colonial Institute of Amsterdam, 1, no. 3 (May 1938), p. 2.

70. Ibid., p. 6. 
As Indonesian writers, whatever the language they wrote in, came to know all too well, the editors of Balai Pustaka could, and did, exercise their powers not only in the diffuse matter of aesthetic "acceptability," but also in a more directly censorial fashion, especially with respect to material considered morally, religiously, or politically contentious. A vivid example of the application of this censorship is given in Balai Pustaka records relating to the alterations forced upon Abdoel Moeis' novel Salah Asuhan. ${ }^{71}$ Yet Hooykaas can criticize Balai Pustaka's Javanese novelists for completely failing to portray "religious spirit or the search for power and political ambition." 72

Both before and after publication, Javanese writers were subjected to the disparagement of scholarship linked to imperial power. Today, unfortunately, contemporary Javanese literature still grapples with the academic offspring of this old adversary.

\section{III. "Basa Jawi sampun risak!"}

It is becoming increasingly apparent that the category in Javanese society called priyayi is a very heterogeneous one, and that among its principal fissures has been the distinction between conservative and progressive. ${ }^{73}$ Much of the tension between conservative and progressive priyayi is attributable to the impact of European power. As Tony Day has shown, already in the nineteenth century, despite the somewhat cushioned impact of European power in the "vorstenlanden" of Central Java (the principalities of Surakarta, Ngayogyakarta, Mangkunegaran, and Pakualaman), the priyayi of this Javanese heartland found themselves faced with a real threat to their authority, identity, and cohesion through the increasing intrusion of European political power, and European practices in education and administration. ${ }^{74}$ By the end of the century, the immediate bearers of this threat were themselves priyayi, products of the Dutch government's nascent education system. Savitri Scherer has provided exemplary documentation of the tensions which developed between the ningrat [hereditary officeholder] priyayi and conservative priyayi bureaucrats on the one hand, and on the other hand the professional, that is Western-educated priyayi and more progressive bureaucratic priyayi. She notes that at the turn of the century non-ningrat priyayi were propelled into a competitive situation:

Because the priyayi positions in the administration were open for competition, individual achievements and qualifications were the criteria for success more than traditional family connections. ${ }^{75}$

71. See Sjafi Radjo Batuah, "Di Balik Tirai Salah Asuhan," Pustaka dan Budaya, 5 (Nov.-Dec. 1964), pp. 30-39.

72. Hooykaas, "Javaansche Uitgaven," p. 115.

73. Clifford Geertz, The Religion of Java (Chicago: University of Chicago Press, 1960), pp. $231 \mathrm{ff}$. The character of the priyayi and the divisions within the category are discussed in Heather Sutherland, "The Priyayi," Indonesia, 19 (April 1975), pp. 57-77; Harsja Bachtiar, "The Religion of Java: A Commentary," Majalah IImuIlmu Sastra Indonesia, 5, no. 1 (Jan. 1973), pp. 85-115; Savitri Scherer, "Harmony and Dissonance: Early Nationalist Thought in Java" (M.A. thesis, Cornell University, 1975), ch. 1; and Day, "Meanings of Change."

74. See Day, "Meanings of Change."

75. Scherer, "Harmony and Dissonance," p. 7. 
While a priyayi apprenticed in the traditional fashion might have to wait many years for appointment to a well-paid, high-status position, graduates of Dutch schools received high starting salaries and were promoted quickly. On the other hand, priyayi who had been trained as doctors and teachers in Dutch schools, and who commanded substantial salaries in their respective professions, were accorded low status by the priyayi of the administrative service. The relentless pressure on the conservative, "bureaucratic" group led its members to turn even more than before to the past to justify their power, and they became hostile to the "professional" group and its cultural accoutrements. ${ }^{76}$

A great deal of this hostility came to focus on the issue of the status and purity of the Javanese language and Javanese literature. Novelist Jasawidagda says he first thought that "something was amiss" [wonten raos-raos ingkang boten sekeca] with Javanese in the years between 1912 and $1920,{ }^{77}$ although others date the appearance of their unease somewhat earlier. ${ }^{78}$ Like many of his contemporaries, Jasawidagda attributes the perceived decline in the status and purity of Javanese to the effects of European-style education. ${ }^{79}$ Since 1875 , instruction at the medical school STOVIA (School tot Opleiding van Inlandsche Artsen) in Jakarta, where some Javanese priyayi studied, had been in Dutch, and in the OSVIA (Opleidings School van Inlandsche Ambtenaren) and Kweekschool (Teacher Training School) the medium of instruction was Malay. In 1907, the Javanese-language primary schools, Inlandsche Scholen der Iste Klasse, which had been established in 1893 . began to offer Dutch as a subject, and in 1914 they were reorganized and became the Dutch-medium HIS (Hollandsch-Inlandsche Scholen), in which Javanese was taught, through Dutch, as one subject among many. Dutchmen dominated HIS headmasterships, and Javanese as a subject was accorded status clearly inferior to that of Dutch. Moreover, the Indies government encouraged the publication and study of Javanese texts in Latin script, measures regarded by some as an attempt to bring about the death of Javanese. 80

Many priyayi, both progressive and conservative, were alarmed at these developments, but it was the conservative, traditionally apprenticed priyayi who felt

76. Windudipuro says that in the early years of the century the objects of upper echelon priyayi enmity were "the upstarts who were leading the struggle for the nation's independence" and, interestingly, in the case of Yogyakarta priyayi, the businessmen [wong sudagaran] of Kutha Gedhe. See A. Windudipuro, "PriyayiismaFeodalisma-N eo Feodalisma," Jaya Baya, 28, no. 8 (Oct. 21, 1973), pp. 16-17, 22. Imam Supardi comments on the hostility of court priyayi to the often irreverent Javanese-language newspapers of Surakarta around the turn of the century. See Imam Supardi, Ki Padmosusastro (Surabaya: Panjebar Semangat, 1961), p. 45. See also Akira Nagazumi, The Dawn of Indonesian Nationalism: The Early Years of Budi Utomo, 1908-1918 (Tokyo: Institute of Developing Economies, 1972), pp. 22 ff.; Robert Van Niel, The Emergence of the Modern Indonesian Elite (The Hague/Bandung: van Hoeve, 1960), pp. 27 ff.; and Day, "Meanings of Change."

77. Jasawidagda, "Wawasan Bab Mekaripun Basa Jawi," Medan Bahasa, Basa Jawi, 2 , nos. 1-3 (1957), p. 46.

78. See for example R. Edroes, "Basa Jawa," Jaya Baya, 28, no. 14 (Dec. 2, 1973), pp. 16-17.

79. See also Sastrawirja, "Mawas Bab Mekaring."

80. See Soegarda Poerbakawatja, Pendidikan Dalam Alam Indonesia Merdeka (Jakarta: Gunung Agung, 1970), pp. 30-32; Sastrawirja, "Masa Bab Mekaring," pt. 4, p. 17; and Jasawidagda, "Wawasan," pp. 46-47. 
most threatened. Jasawidagda records the resentment of traditionally apprenticed priyayi in the Surakarta kapatihan [chief administrator's office] at being passed over in favor of Dutch-speaking HIS graduates.

In the Surakarta kapatihan, newly graduated students from the HIS who could scarcely even sit properly on the floor, and who could not speak good Javanese nor write it well, were immediately appointed to jobs with a salary of 10 guilders a month, and they received a monthly bonus of 15 guilders in recognition of their HIS diploma. . . . You can just imagine the feelings of assistant clerks who had been in service for 10 years, but who could only speak Javanese. ${ }^{81}$

The reaction of conservative priyayi was to attempt to put the intruders in their place and bolster their own authority by stressing the niceties of etiquette and expecting a good command of Javanese, especially unggah-ungguh [honorific vocabulary]. These tactics were successful to an extent, for, as Jasawidagda recalls, graduates of HIS, MULO, and ASM, and even tertiary-level students, avoided meeting their priyayi superiors for fear of putting a foot wrong.

Especially harsh were the high-level priyayi who had no interest in nationalist ideals. If they felt offended at some infraction of etiquette they did not hesitate to vent their anger [sesiku] on the offender, and they ridiculed faults in mastery of Javanese. ${ }^{82}$

Reaction produced counterreaction. Partly in response to the difficulty of mastering unggah-ungguh, and partly inspired by the incipient egalitarianism of nationalist sentiment, a movement sprang up in 1917 dedicated to the abolition of krama [respectful] vocabulary. ${ }^{83}$ Called Jawa-Dipa, the movement had early connections with Sarekat Islam but, at least according to Edroes, its rise was marked by a good deal of spontaneity. Chapters sprang up, with their principal support coming from educated youth, many from priyayi backgrounds. Needless to say, conservative, high-ranking priyayi were incensed at being addressed in ngoko [low Javanese], and, as both Bonneff and Edroes report, they refused to reply to anyone who did not use krama. ${ }^{84}$ The movement gradually lost its impetus and by the late $1920 \mathrm{~s}$ had disappeared. Another strategy for avoiding the pitfalls of unggahungguh was to use Malay, but conservative priyayi were unimpressed with the rising status of the language. They considered Malay to be unrefined [kasar] and if addressed in it felt insulted ["menawi dipun srawungi mawi basa Melayu, rumaos dip un sembranani"]. ${ }^{85}$

81. Jasawidagda, "Wawasan," p. 48. According to Jasawidagda, the average assistant clerk with five or six years as a magang [apprentice clerk] and three or four years as a jajar [unranked clerk] behind him received 10 guilders a month.

82. Ibid., p. 49.

83. Uhlenbeck, Critical Survey, p. 70, gives circa 1910 as the year in which the Jawa-Dipa movement appeared, but Bonneff gives the more precise foundation year of 1917. See Marcel Bonneff, "Un Aperçu de l'Influence des Aspirations Démocratiques sur la Conception et l'Usage des 'Niveaux de Langue' en Javanais: Le Mouvement Djowo-Dipo et ses Prolonguements," in Papers on Indonesian Languages and Literatures, ed. Nigel Phillips and Khaidir Anwar (Cahiers d'Archipel, 13) (London: School of Oriental and African Studies, University of London; and Paris: École des Hautes Études en Sciences Sociales, 1981).

84. See Bonneff, "Aperçu de 1'Influence," especially pp. 43 and 50, n. 20, and also Edroes, "Basa Jawa," p. 16.

85. Edroes, "Basa Jawa," p. 16. 
The use of Malay in the nascent nationalist movement was, in the eyes of conservative priyayi, a blow to the prestige of Javanese, and must have been one reason (though probably a minor one) why some of them did not support Budi Utomo, despite the organization's strong Javanese character and its general dedication to priyayi interests. ${ }^{86}$ Moreover, Malay-language newspapers, with their frequently blunt criticisms of Javanese officials, did nothing to endear Malay to the conservative priyayi. ${ }^{87}$ Balai Pustaka, too, seemed to some to be working for the denigration of Javanese. Besides issuing Javanese works in Latin script, Balai Pustaka distinguished in its libraries between Javanese-language books for children and adults, and Malay-language books for "meer ontwikkelden" [more advanced] readers. ${ }^{88}$

I have outlined the various factors which, culminating in the first two or three decades of the century, brought conservative, bureaucratic priyayi to a realization that the linguistic and literary norms which had been important, indeed indispensable, props in the structure of their hegemony, were coming under assault. Their reaction, characteristically, was to dig in, to raise the catchcry "Javanese is in ruins!" [Basa Jawi sampun risak!], dismiss contemporary developments in literature, and advocate a return to veneration for the language and literature of what was perceived as the "Golden Age" of their power, the era prior to the late nineteenth century. ${ }^{89}$ This endeavor crystallized around one figure, the "last of the pujangga," Raden Ngabei Ranggawarsita, who had died in 1873. The mythologization of the "last pujangga" in the early decades of the twentieth century, and the subsequent vigor of the Ranggawarsita myth, are worth a glance here for the oppressive shadow they throw over the reception accorded contemporary Javanese literature.

Pujangga in its narrow sense was a title borne by the leading figures in a line of belletrists at the Surakarta court in the nineteenth century. 90 In this sense, Ranggawarsita was indeed the last of the pujangga, for no one after him has been referred to by this title. When exactly the predicate "last of the pujangga" (pujangga panutup) was applied to Ranggawarsita is not clear, although Drewes asserts that Ranggawarsita was already so called during his lifetime. ${ }^{91}$ In any

86. During the 1920 s some elements in the more conservative Javanese cultural organizations apparently harbored hopes that Javanese might become the national language of the Indies; see Bonneff, "Aperçu de 1'Influence," p. 44.

87. See Imam Supardi, Ki Padmosusastro. Soebagijo cites several cases of conflict between muck-raking journalists and conservative priyayi officials; see Soebagijo I. N., Sebelas Perintis Pers Indonesia (Jakarta: Djambatan, 1976), for example, p. 28 .

88. D. A. Rinkes, "Volkslectuur," in Encyclopaedie van Nederlandsch-Indië, 4, p. 611, and Balai Pustaka Sewajarnya 1908-1942 (Jakarta: Balai Pustaka, 1948), p. 9.

89. For a heartfelt analysis of the sources and character of the alleged "ruin" in Javanese, see R. Susanto Gunoprawiro, "Risaking Basa Jawi," pt. 1, Djaka Lodang, 10 , no. 450 (1981), pp. 8-9; pt. 2, ibid., 10, no. 451 (1981), pp. 22-24.

90. As Day, "Meanings of Change," p. $170 \mathrm{n} \cdot 13$, observes, the exact meaning of pujangga and the precise duties of a pujangga are not entirely clear. Day suggests that pujangga was a purely honorary title, but Drewes, "Ranggawarsita," p. 212, asserts that the pujangga dalem at the Surakarta court was "head of the literary and historical section of the kraton office, at the same time court historiographer and poet-laureate."

91. Drewes, "Ranggawarsita," p. 199. 
case, by the turn of the century, the appellation and the poet's name were synonymous.

Drewes argues that the honorific term "last of the pujangga" was applied to Ranggawarsita in a somewhat narrow sense. The poet was perceived as having brought to completion a great and clearly defined literary project, namely the writing in poetry and prose of a comprehensive history of Java. Whether this is true or not, it does seem clear that in the decades following the poet's death a subtle change came over the notion of "the last pujangga." Instead of referring only to a particular individual who had held a particular "office" in the Surakarta court and who had perhaps brought to completion a particularly significant task, it came to be linked with the condition of Javanese literature in general. The implication that Ranggawarsita would never have a successor became more explicit. No future pujangga was possible and no future Javanese literature was possible. Ranggawarsita was the "seal of the pujangga," just as Muhammad was the seal of the prophets. ${ }^{92}$ In Ranggawarsita Javanese literature reached at once a sanctified completeness and a zenith of brilliance. Any subsequent writing was not merely ipso facto of poorer quality or simply superfluous, it was almost heretical, an act of irreverence, a disgrace to the memory of the great man and the great tradition. Javanese literati had now to apply themselves to the care of the heritage, to its study and its propagation.

In a study of myth in the contemporary world, Locher points out that Dipanagara acquired certain mythical attributes as a consequence of Indonesia's revolutionary struggle and its independence. The new Dipanagara myth, he says, "had grown under Western influence." 93 Similarly, I suggest, in the decades straddling the turn of the century, the struggle by conservative priyayi to defend themselves against the attrition of Western influence invested Ranggawarsita with mythic attributes. In effect, a contest emerged between two views of Java's history. On the one hand, eulogized by conservative priyayi, lay Ranggawarsita's monumental historical writings. The pujangga's project had been to create history out of literature, or, more aptly perhaps, to reaffirm the unity of literature, the literary imagination and history. It is interesting that Ranggawarsita seems to have undertaken this endeavor in spite of close contacts he had with European and Eurasian scholars. On the other hand lay the work of European scholars, whose project was to divorce history and literature in the study of Java's past. European-educated Javanese, the "progressive" aristocrats and priyayi, such as historian Hoesein Djajadiningrat and philologist R. M. Ng. Poerbatjaraka, sided with their mentors in affirming the superiority of the new scholarship. Tony Day gives instances of this tension in his study of nineteenth century Javanese court poetry :

In 1860, when the Dutch Indologist, A. B. Cohen Stuart, published the first philologically prepared edition of a Javanese literary text he ridiculed Ranggawarsita's ignorance of Old Javanese. By the end of the nineteenth century the fraudulence of Ranggawarsita's claim to authority on ancient Javanese traditions had been proven beyond doubt in the minds of the Dutch when the learned society in Batavia, the Bataviaasch Genootschap, discovered that the Pustaka Raja was not, as Mangkunegara IV had indicated when he sent a portion of it to Batavia in 1880 , one of the most ancient and authentic records of Java's early history. The disdain which the Surakarta-born, Leiden-trained philologist, R. Ng. Poerbatjaraka, displayed for Ranggawarsita in his philo-

92. Roosman, "Eb en Vloed," p. 107, and Drewes, "Ranggawarsita," p. 212.

93. G. W. Locher, "Myth in a Changing World," Bijdragen tot de Taal-, Land-en Volkenkunde, 112 (1956), p. 184. 
logical writings, entirely justified from the philological point of view of a scholar of Old Javanese but oddly insistent all the same, reveals the extent to which Poerbatjaraka's own scholarly career was in part a project to escape the opprobrium which automatically attached itself to "traditional" Surakarta Javanese literati after Ranggawarsita. ${ }^{94}$

Yet despite the thorough discrediting of Ranggawarsita's authority as historian, and even to some extent as writer, the myth of the last pujangga remains determinedly alive. In fact, the remarkable burgeoning of the myth in more recent times suggests that other factors have contributed to its growth and still continue to nourish it.

Traditionally, Javanese literati have held that pujangga possess extraordinary powers bestowed upon them by divine grace. ${ }^{95}$ These powers are manifested in their literary creations, not only in the masterly literary skills these creations exhibit, but also in their frequent use in ritual contexts, where literary works are credited with exceptional, even magic, power. But Ranggawarsita's literary works, like those of all pujangga, are not well known among ordinary Javanese. Ranggawarsita's popular fame (and he is a household name throughout the Javanese-speaking region) stems from many folk anecdotes of his supranormal powers, and from fragmentary knowledge of his prophetic writings, rather than from widespread and direct appreciation of his histories and other more substantial works. ${ }^{96}$

Of the many miraculous talents attributed to Ranggawarsita, none more predominates in the popular imagination today than that of prophecy. ${ }^{97}$ The power of clairvoyance is reputed to have been inherited by Ranggawarsita from his greatgrandfather, the court pujangga Yasadipura I, who, legend relates, predicted on his deathbed that Ranggawarsita would be a pujangga whose fame would exceed that of his grandfather and great-grandfather, and who would be the last pujangga. ${ }^{98}$ Popular opinion has ascribed to Ranggawarsita many predictions relating to the decline of Dutch power in Indonesia and the triumph of Indonesian nationalism. This suggests that Ranggawarsita has been incorporated into the popular millenarianism of Java in much the same way that Dipanagara has been. An example from the extensive body of Ranggawarsita "apocrypha" will serve to illustrate this point:

One day the Dutch sent one of their men, a certain Frederik de Winter who was a friend and pupil of Ranggawarsita's, to test the pujangga's loyalty to the Dutch government.

94. Day, "Meanings of Change," p. 187.

95. Ranggawarsita, for example, is reputed to have had divine poetic gifts bestowed upon him at the age of nine in the form of a revelation from Sunan Kalijaga (one of the nine semilegendary missionaries who first spread Islam in Java); see Kamajaya, Zaman Edan (Yogyakarta: U. P. Indonesia, 1964), p. 25, and Day, "Meanings of Change," p. 169.

96. See S. R. Goenawan, "Pujangga Ageng Ranggawarsita," Mekar Sari, 3, no. 14 (Sept. 15, 1959), pp. 3-4.

97. See, for example, Marsan, "Pujangga Terakhir Surakarta Adiningrat," Syara Merdeka, June 23, 1978, p. 3; "Perlu Yayasan 'Sponsor' untuk Segala Kegiatan Sastra Jawa," Sinar Harapan, Jan. 9, 1980; and Day, "Meanings of Change," pp. 192-93.

98. H. Srojo, "Silsilahe Swargi R. Ng. Ranggawarsita," Jaya Baya, 28, no. 15 (Dec. 9, 1973), p. 8. 
"Honored Pujangga," said Frederik de Winter, "Do you predict that Dutch power in the Netherlands Indies will come to an end?"

Ranggawarsita was somewhat startled at this question, but because he possessed the power of omniscience, he perceived at once that his allegiance to the Dutch was being tested. He could never bring himself to lie, yet if he told the truth he would be murdered as his father had been. So the great pujangga gave his answer in a literary disguise.

"Dutch power will only come to an end," he said, "when bamboo can produce paddy."

This answer was conveyed to the Dutch government who were gratified. Bamboo could never produce paddy, so it meant that Dutch power in the Indies would last forever.

However, in 1939 when Susuhunan Pakubuwana X died, the Dutch Resident, whose name was Ori,proposed Prince Hangabei, the eldest son of the unofficial wife, as Pakubuwana XI, the successor. And thus the prophecy was fulfilled. "Ori" is the name of a variety of bamboo. The figure XI when written in Javanese script (arnan) also spells the word "gaga" which means rice grown on unirrigated ground. So "ori" bamboo had produced "gaga" paddy. Two years later in 1942 the Japanese came and brought down Dutch power. ${ }^{99}$.

Ranggawarsita's jangka [prophetic writings], especially Jaka Lodhang, are believed to refer to social conditions in the twentieth century, and in particular to the coming of Indonesia's independence. Jaka Lodhang contains the chronogram [sengkalan] wiku sapta ngesthi ratu (AJ 1877) which corresponds to AD 1945/1946, and the stanza in which it appears is interpreted as foreshadowing the coming of justice and compassion for ordinary people. ${ }^{100}$ That Ranggawarsita's prophecies were known and quoted at the time of Indonesia's independence is well attested. ${ }^{101}$ Writing in the Javanese magazine Jaya Baya in 1946, Brotokesowo urged readers to ponder the significance of Jaka Lodhang. He linked stanzas eight (in which the above sengkalan appears) and nine with President Soekarno's radio speech of January 5, 1946, calling upon the Indonesian people to regard 1946 as a year for getting organized.

Readers, there can be no error here. Our conviction that this year of 1946 is a year of decision, and our conviction that Jaka Lodhang's prophecies are true must become manifest in action and in efficient organization as our President exhorts. Ki Jaka Lodhang also urges us to "esthinen murih kelakon" [dedicate ourselves to getting things done], and "ngesthi" means unstinting dedication, physical and spiritual. ${ }^{102}$

99. From Sekitar Ki Pujangga Ranggawarsita by Ki Soemidi Adisasmita, quoted in Soemarno P. Wirjanto, "R. Ng. Ronggowarsito III, Pujangga Nasional Indonesia" (Paper presented at the Seminar Peringatan Pujangga Besar Ronggowarsito, University of Indonesia, Jakarta, Jan. 3, 1980), pp. 5-6.

100. See, for example, Mardhibudi, Jangka Jaka Lodhang Kawedhar (Madiun: Guru-Budhi, 1956[?] ), pp. 15, 32 .

101. In his recent novel of the Japanese occupation, Kalah dan Menang [Defeat and Victory], 1978, Takdir Alisjahbana makes several references to the role of prophetic writing in Indonesia's nationalist struggle; see for example p. 449 . See also Tjantrik Mataram (pseud.), Peranan Ramalan Joyoboyo Dalam Revolusi Kita (Bandung: Masa Baru, 1966).

102. Brotokesowo, "Jaka Lodhang," Jaya Baya, 1, no. 6 (Feb. 17, 1946), pp. 10-11. 
On November 11, 1953, President Soekarno recalled Ranggawarsita's role in the Revolution in a speech delivered at the dedication of a bronze bust of the pujangga erected before the Radya Pustaka museum in Solo. Soekarno described the sacrifices made by Indonesians in the struggle for independence and said that Ranggawarsita's words gave the Indonesian people strength. He declared that Ranggawarsita was a "pujangga rakyat" [a pujangga of the ordinary people], a title which has proved durable. ${ }^{103}$ In 1955, the President made a pilgrimage to Ranggawarsita's grave at Palar, near Klaten. ${ }^{104}$ Today, the poet's grave is still revered as a holy spot, a place where one can retreat to meditate [nenepi] and where one can expect to receive supernaturally conveyed communications or advice [dikethoki]. ${ }^{105}$ Such has been the popular power of the myth in national politics that in the 1960 s the Indonesian Communist Party even named an Academy of History after the great poet of Surakarta's feudal court and darling of Java's haughty, aristocratic elite. ${ }^{106}$ In a recent commemorative seminar on Ranggawarsita, one participant vociferously advocated raising him to the status of "Pujangga Nasional" and teaching his works in schools not only in Javanese-speaking areas, but throughout Indonesia. ${ }^{107}$

Like President Soekarno, conservative priyayi in postindependence Indonesia have not been slow to appropriate to their own purposes the populist, prophetic aspects of the myth. Ranggawarsita's clairvoyance is seen as an inalienable facet of his exceptional literary gifts. Seeking to give more rigorous expression to this idea, critic Sutadi Wiryatmadja cites the opinion of W. H. Hudson that great poetry has revealing power, that is, he says, it has the power to reveal essential truths, and the clairvoyant variant of this power is evident in the poetic genre called jangka.

A jangka is an expression of clairvoyance [kewaskitaan], that is, it gives a view of events which will happen in the future. A great poet can be gifted with the power of foresight, the capacity to see with his inner eye events which will occur even in the very distant future. This is not an impossible notion or some invention peculiar to the Javanese cultural tradition. From ancient times up to the present the truth of this idea has been recognized in European culture. In ancient Greece the oracles of Delphi, Sybil, and Tiresias were renowned. The latter two are mentioned by T. S. Eliot in his Nobel Prize-winning poem The Waste Land as poetic personae who possessed clairvoyant powers. The celebrated American poet Richard Eberhart in his poem Dialogue also describes poets as individuals who have the power of foresight. 108

103. Kamajaya, Zaman Edan, pp. 18-20.

104. S. H. Kusumo, "Palar dan Ranggawarsita," Sana Budaya, 1, no. 5 (May 1957), p. 236.

105. Marsan, "Pujangga Terakhir."

106. Soebagijo, Sebelas Perintis, p. 1.

107. See Soemarmo, "R. Ng. Ronggowarsita."

108. Sutadi Wiryatmadja, "Telaah Beberapa Karya Ronggowarsito" (Paper presented at the Seminar Peringatan Pujangga Besar Ronggowarsito, Jan. 3-5, 1980), p. 4. Sutadi refers here to W. H. Hudson's An Introduction to the Study of Literature. 
The millenarian character of the Ranggawarsita myth is evident in its dichotomous face. On the one hand, his Kalatidha paints a compelling portrait of the conditions and conflicts society faces in the "Age of Madness" [jaman edan] which is usually taken to be the present. The poem recommends an attitude of "awareness and vigilance" [eling lawan waspada], advice eminently palatable to Java's harassed and fundamentally cautious peasantry. On the other hand, many phrases in his works hold out, or are interpreted as holding out, the promise of a future era of brilliance. Through the agency of Soekarno, Muhammad Yamin, and other nationalist mythmakers, Ranggawarsita's promise of the millennium has become merged with Indonesia's national myth--the promise of prosperity embodied in the independent nation state. Conservative priyayi have made the most of the popular currency and national status of the myth to lend support to their claim of special prestige for the "last pujangga" and the literary norms he represents. From this fortress they have directed hostile criticism at the innovative writing of the twentieth century.

Comparing the old pujangga of Java with the new ones of the "Age of Apollo," S. Hadiwijono notes that, whereas the pujangga of old had their gifts divinely bestowed upon them after a period of ascetic petition [laku and sujud], the modern pujangga arrives at his status through his own efforts. ${ }^{109} \mathrm{He}$ is not necessarily deeply versed in mysticism [ahli kabatinan] and his work consequently suffers from human failings and the absence of divine inspiration. Not only is contemporary writing frivolous, but it cannot aspire to be otherwise, since modern writers lack the fundamental strengths of the old pujangga. ${ }^{110}$ Budya Pradipta asserts that contemporary Javanese literature is superficial because it has lost three fundamental elements, mystical philosophy [sangkan paraning dumadi], intuitive perception [rasa], and the outward, controlled practice of inwardly perceived truths [laku], all of which are present in the great works of traditional Javanese literature. Having lost these qualities, contemporary Javanese literature has been incapable of resisting invasion by foreign influences, and these influences have produced a shift in the value orientation of Javanese writers. From being concerned with spiritual values, Javanese writers have turned to the superficial values of materialism. ${ }^{111}$ He claims that because of this, contemporary writing, unlike traditional literary arts such as wayang theater and tembang poetry, has failed to excite the interest of Javanese people at large. ${ }^{112}$

The contention that the Javanese language is now in decay or in ruins [rusak] is also a principal weapon in the battery turned against contemporary writing. Works are judged on linguistically conservative grounds and, as critic Subalidinata remarks, an entire work is sometimes condemned out of hand for a minor grammatical "indiscretion." 113 Conservative observers deplore changes in grammatical

109. S. Hadiwijono, "Kalenggahan Pujangga," Kunthi, 4, no. 11 ([1975]), p. 15.

110. Singgih Wibisono, "Pelembagaan dan Pengkomunikasian Kegiatan-Kegiatan Sastra Jawa" (Paper presented at the Seminar Peringatan Pujangga Besar Ronggowarsito, Jan. 3,1980 ), p. 4 .

111. Budya Pradipta, "Makna dan Manfaat Sastra Daerah Lama untuk Pengembangan Sastra Daerah Baru" (Paper presented at the Seminar Pengembangan Sastra Daerah, Jakarta, Oct. 13-17, 1975), p. 13.

112. Ibid. See also Linus Suryadi A. G., "Pujangga Jawa Tempo Dulu dan Pujangga Sekarang," Kedaulatan Rakyat, June 13, 1978, p. 5, for a similar view.

113. R. S. Subalidinata, "Bahasa Sebagai Perabot Utama Sastra Jawa" (Paper presented at the Sarasehan Sastra Jawa 1979, Pusat Pengembangan Kebudayaan Jawa 
conventions. They tend to be particularly upset at the influence of Indonesian grammar on Javanese. This not only offends against the purity of Javanese, but is in any case aesthetically undesirable. ${ }^{114}$ Another component in the "rusak" notion is that of change in the character of unggah-ungguh. This not only relates to the now almost universal adoption of ngoko as the narrative medium, but also to the allegedly incorrect use of unggah-ungguh in passages of direct speech. ${ }^{115}$ The use of slang and regional dialect is likewise deemed unseemly, and even after the Revolution one still occasionally heard a diehard voice bemoaning the abandonment of Javanese script in literary publications. ${ }^{116}$

To help effect a return to conservative values in language and literature, priyayi have utilized institutional authority. No doubt this is a reflex related to the formerly all-powerful position of the palace (kraton) as the determinant of artistic values. Writing in 1975 , Budya Pradipta could still lament the passing of kratoncentered authority in literary matters.

Pujangga like Mpu Kanwa, Mpu Sedah, Mpu Panuluh, Mpu Tanakung, Mpu Tantular, Kyai Ronggowarsito, Kyai Yosodipuro I and II, Kyai Ronggosutrasno and many others who in kraton times lived within the court confines together with pujangga of other arts, raised the kraton up to a radiant object of popular pride. The quality of literary works and other artistic creations produced at court was always carefully maintained. Court art was refined and noble, never harsh, and it always accommodated moral instruction. In screening its artistic creations the kraton performed a valuable service which should never be forgotten. Many kraton creations became accepted by the public as classics. Even today kraton standards are still applied-though not all of them and to an ever decreasing degree--especially in wayang theatre, classical dance, classical music, and kris manufacture. But it is almost impossible, it seems, to find acceptance for kraton standards in contemporary literature. ${ }^{117}$

The new "kraton," evidently, are Indonesia's universities, though I hasten to add that this is not true of the more practically oriented Teacher Training Universities (IKIP). In the major universities where Javanese literary studies are to be found, the University of Indonesia (Jakarta), Gadjah Mada University (Yogyakarta), the University Sebelas Maret (Solo), and Diponegoro University (Semarang), the emphasis is very firmly on premodern forms, as the statistics on theses given above ( $p$. 5) indicate. Moreover, a number of academics, with conservative ideas

Tengah, Solo, May 28-31, 1979), p. 2; also 'Tera' [Suparto Brata], "Pamilihan Tema Ing Crita-Crita Basa Jawa," Jaya Baya, 24, no. 25 (March 1, 1970).

114. Subalidinata, "Bahasa Sebagai Perabot Utama." See also Susanto Gunoprawiro, "Risaking Basa Jawi."

115. Especially galling is the deliberate rejection of formal literary language and Solo-Yogyakarta conventions of unggah-ungguh by some popular writers; see Sri Hadidjojo, Setan Gundhul Bale Kambang, 2 vols. (Semarang: Keng, 1966), preface ; and Bratasoetarya, Ontran-Ontran ing Banjaranom (Yogyakarta: Ganefo, 1965[?]), preface.

116. See for example Soemitro Hp., "Aksara lan Basa Jawa Arep Sirna?" Panjebar Semangat, Feb. 6, 1954, pp. 8-9.

117. Budya Pradipta, "Makna dan Manfaat," p. 10. See also T. Hadiwiryanto, "Basa Jawa Manjing Ing Tataran Klasik," pt. 1, Djaka Lodang, 9, no. 376 (May 15$25,1979), p .33$. 
on what Javanese literature is or should be, have attempted to promote their views by seeking to forge links between organized literary activity and the academic establishment. In the commemorative Ranggawarsita seminar of 1980 held at the University of Indonesia, lecturer Singgih Wibisono discussed how best to restore vitality to Javanese literary life. He recommended annual conventions and the establishment of an "executive body" [badan penyelenggara].

. . . this body should be permanent and its leading members drawn from lecturers and students in the Javanese departments of universities. The reason for this is that these lecturers and students are engaged in specialist study in the field of Javanese language and literature and therefore have a committed interest in all Javanese literary activities. So this body should be set up in university cities where Javanese departments are to be found. ${ }^{118}$

Indeed, conservative influence has been marked in existing or now defunct Javanese literary organizations, and conflict of one kind or another between conservative and progressive elements within such organizations may in part account for the feeble performance of organizations in contemporary literary life. The Organization of Javanese Writers [Organisasi Pengarang Sastra Jawa], established in 1966 at the initiative of the innovative artists' association Bamboo Studio ' 59 [Sanggar Bambu 59] came under early pressure from conservative elements, and has since remained a moribund presence on the literary scene. ${ }^{119}$ The Jakartabased Association for the Promotion of Javanese Literature [Himpunan Pemersudi Sastra Jawa], established in 1976, was formed at the combined initiative of the Department of Javanese at the University of Indonesia and the conservative (and now defunct) magazine Kunthi, together with the more innovative (also now defunct) magazine Kumandang and representatives from Jakarta's Javanese-language radio stations. Although the association did not entirely eschew interest in contemporary writing, the essential character of its concerns, and the way in which conservative forces seek to work through the authority of organizations, is evident in the press release issued at the time of its foundation.

The 1st. of Suro has been chosen as the date for the birth of the Association for the Promotion of Javanese Literature because most ordinary Javanese people believe that the 1st. of Suro possesses "background histories" [ sic], that is, the date recalls the past and reminds us to hand on the heritage of our ancestors whose genius and dedication contributed to the abiding vitality of Javanese language and literature. ${ }^{120}$

IV. Kami,poetra dan poetri Indonesia, mendjoendjoeng bahasa persatoen, bahasa Indonesia

Discussing cultural dynamics in recently independent states, Clifford Geertz draws a useful distinction between two ideological complexes, essentialism and

118. Singgih Wibisono, "Pelembagaan dan Pengkomunikasian," p. 4.

119. Elsewhere I describe the actions of the Surakarta police chief at the time of the organization's establishment. In his capacity as advisor to the organization's journal Gumregah, he advocated adherence to classical literary norms, and at the same time used his police power to seize and prohibit popular novels in Javanese; see George Quinn, "Panglipur Wuyung: Javanese Popular Novels in the $1960 \mathrm{~s}$, " in Society and the Writer: Essays on Literature in Modern Asia, ed. Wang Gungwu, M. Guerrero, and D. Marr (Canberra: Australian National University, 1981), pp. 104-5.

120. See "Sastra Jawa Surut Pamore, Mula 'Himpunan Pemersudi Sastra Jawa' Madeg," Kumandang, 3, no. 115 (Jan. 1976), p. 1. 
epochalism. Essentialism denotes that component in ideologies which stresses local mores, established institutions, and the unities of common experience, that is, the indigenous way of life. Epochalism stresses the general outlines of the history of our time, and, in particular, what is regarded as the overall direction and significance of that history. Epochalism, in short, seeks to embrace "the spirit of the age." 121 In only a few states, says Geertz, does one or the other tendency predominate. Most newly independent countries, committed to the internal process of forging a viable collective identity and at the same time to creating a modern society internationally recognized and respected, draw upon both themes. The conflict between the two is sometimes acute and is nowhere better illustrated than in the almost universal occurrence of dispute over national languages. Geertz aptly puts the dilemma this way:

For any speaker of it, a given language is at once either more or less his own or more or less someone else's, and either more or less cosmopolitan or more or less parochial--a borrowing or a heritage; a passport or a citadel. The question of whether, when, and for what purposes to use it is thus also the question of how far a people should form itself by the bent of its genius and how far by the demands of its times. ${ }^{122}$

From its earliest days the Indonesian nationalist movement used Malay, later called Indonesian (Bahasa Indonesia). ${ }^{123}$ In 1928, the Second Congress of Indonesian Youth, held in Jakarta,proclaimed "We, the sons and daughters of Indonesia, accord pride of place to the language of national unity, Indonesian, "124 and when the country declared its independence in 1945, Indonesian was endorsed as the Republic's sole official language. While there has been little dispute over which language was to become the principal vehicle for nationalist ideals, unease and illfeeling arose over the role of the national language, and, in particular, over its impact on regional languages. In Geertz's terms, the epochalist character of the cultural variant to which Indonesian gave expression clashed with the essentialism expressed through the regional languages. Describing this kind of conflict in general terms, Geertz says:

What, from the ordinary speaker's view, is the natural vehicle of thought and feeling (and particularly in cases like Arabic, Hindi, Amharic, Khmer, or Javanese--the repository of an advanced religious, literary, and artistic tradition to boot) is, from the view of the main current of twentieth century civilization, virtually a patois. And what for that current are the established vehicles of its expression, are for the ordinary speaker at best but halffamiliar languages of even less familiar peoples. 125

121. Clifford Geertz, "After the Revolution: The Fate of Nationalism in the New States," in his The Interpretation of Cultures (London: Hutchinson, 1975), p. 240. 122. Ibid., p. 241.

123. It must be remembered, though, that Malay was not used exclusively. Dutch and, to a lesser extent, the major regional languages were used at certain stages and in certain facets of the nationalist struggle, even after the Sumpah Pemuda of 1928.

124. Some Indonesians, including Javanese, have objected to the now almost universal corruption of this formula to "We, the sons and daughters of Indonesia, acknowledge only one language, Indonesian." See, for example, Suripan Sadi Hutomo, "Problematika Sastra Jawa dan Hubungannya dengan Sastra Indonesia," Memorandum, Dec. 23, 1979, p. 11.

125. Geertz, "After the Revolution," p. 242. 
Indonesian could scarcely be characterized as a half-familiar language of an even less familiar people, but the gulf between it and the regional languages (and, for that matter, between one regional language and another) is nevertheless considerable. Despite gestures of protestation to the contrary, Javanese writers feel keenly the nationalist relegation of their language to the status of a patois, or, at best, a provincial language. Poet and critic Muryalelana laments that the Sumpah Pemuda (the Oath of Indonesian Youth) of 1928 was a blow to Javanese language and literature, and that it meant an inevitable alteration in its status.

It [the Sumpah Pemuda] brought about a fall in the status of Javanese. Javanese was seen as being incapable of dealing in the materials of progress, of being a vehicle of the technological advance which was to come. Consequently, it became no more than just another regional language, deprived of the right to be a vehicle of government communication and a language of technology in the age of economic development. ${ }^{126}$

In a somewhat more emotional fashion, poet Anie Sumarno likens the present fate of Javanese to that of a mother abandoned by her children, left grief-stricken, emaciated, and bereft of honor. ${ }^{127}$ Seeing the lack of respect for Javanese in national cultural life, the young writer Yani Koeswa feels grief and compassionate sympathy [trenyuh] for his mother tongue. ${ }^{128}$

Advocates of the unitary, national culture direct two specific and principal objections against the development of a vigorous contemporary literature in Javanese. First, contemporary Javanese literature (indeed for some, any form of Javanese linguistic or artistic vitality) is seen as posing a threat to what is viewed as Indonesia's hard-won and still precarious unity. Second, Javanese language and literature is considered feudal, antimodern, and therefore an impediment to progress. No advocate of this point of view has spoken with more authority and eloquence than Sutan Takdir Alisjahbana.

Writing before independence, Takdir stressed that the national culture of the future Indonesia could not be a continuation of Javanese culture, Malay culture, Sundanese culture, or any of Indonesia's other cultures. The culture of the new state had to be free of provincialist color. The Javanese, he said, would have to give up their Javanese culture, for, if they did not, they would endeavor to bring to Indonesian culture the provincial spirit of Javanese culture. Grafting the new Indonesian culture onto the old regional cultures could only give rise to division

126. Muryalelana, "Sastra Jawa dan Kemungkinan-Kemungkinan Hari Depannya" (Paper presented at the Sarasehan Sastra Jawa, Pusat Kebudayaan Jawa Tengah, Solo, June 20-24, 1977), pp. 8-9. There is an element of hyperbole in Muryalelana's (and others') protestations on the outcast status of Javanese vis-à-vis economic development. One of the fascinating features of Javanese-language magazines in recent years (a development already in evidence when Muryalelana wrote the words I quote) is the regular use of Javanese in articles relating to topics normally thought reserved for discussion in Indonesian. Panjebar Semangat, the largest of the Javanese-language periodicals, regularly runs articles on international and national politics, botany and animal husbandry, agricultural technology and economics, civil (as well as customary) law, and even elementary electronics.

127. In the poem "Pisambat" [An Appeal], in Jaya Baya, 28, no. 8 (Oct. 21, 1973), p. 11 .

128. Yani Koeswa, "Memetri Basa Jawa: Basa Sing Murni Apa Basa Sing Bener," Panjebar Semangat (Dec. 29, 1979), pp. 2 and 35. 
and dispute. ${ }^{129}$ More than forty years later Takdir's views remain essentially unchanged, but, as if in corroboration of Geertz's emphasis on epochalism in national ideologies, he has increasingly stressed the international character of Indonesia's national culture. We should realize, he says, that the question of cultural development in the modern world is a question of global unity, of the unity of all peoples, for modern culture, based on science and economics, has unified the world. Anyone who rejects the equation of modern culture with unity is living in the multifarious past. ${ }^{130}$

Takdir seems to see the international culture of which Indonesia must be part as dominated by the technology and values of Europe. This culture he sees as youthful, progressive, and dynamic, in short, the kind of culture Indonesia must adopt to raise itself to a position of respect in the international community and selfrespect in its own eyes. Indonesia's regional cultures, on the other hand, are static, fragmented, and oriented to the past. Takdir asserts that the regional languages and Indonesian are very different. The regional languages are mirrors of the past, mirrors of regionalism. Indonesian must become the true mirror of Indonesian culture and all its variants, but it is the only Malayo-Polynesian language which has succeeded in becoming modern. The bad influence of regional languages on Indonesian must be resisted, in particular influences relating to the archaic value orientations of the Javanese, such as the distinction between unrefined [kasar] and refined [alus], and feudal, hierarchical distinctions in pronouns of address. ${ }^{131}$

The notion that Javanese is inherently feudal and undernocratic is frequently voiced. Journalist Marbangun Hardjowirogo, for example, son of the Javanese novelist Hardjowirogo and great-grandson of the celebrated pioneer of contemporary Javanese writing Padmasusastra, insists that Javanese exercises a feudal influence over Indonesian inconsistent with the democratic development of national society and the national language. ${ }^{132} \mathrm{M}$. Wonohito, the (then) editor of Mekar Sari quoted the opinion of an unnamed Javanese professor of law, who said that the Javanese people would never go forward until they forgot their language, because as long as they used Javanese they could never be democratic, ${ }^{133}$ while another observer has reported that those who oppose the development of Javanese language and literature are mostly young people who believe that it is saturated with feudal elements and is irreconcilable with modern life and the Indonesian Republic. ${ }^{134}$ At a 1981 conference on Indonesia's multilingualism, Indonesian-language dramatist Ikranegara, for example, is reported to have vigorously attacked the Javanese language as a remnant of feudalism and called for the killing of all such languages. ${ }^{135}$

It takes no more than a glance at recent Javanese literature to scotch any notion that it is antagonistic or antipathetic to Indonesian nationalism in the broad

129. Takdir Alisjahbana, "Menuju Masyarakat dan Kebudayaan Baru [1948]," in Polemik Kebudayaan, ed. Achdiat K. Mihardja (Jakarta: Perpustakaan Perguruan, Kementerian P.P. dan K., 1954), pp. 16-18.

130. Takdir Alisjahbana, "Kebudayaan Harus Berpokok pada Ilmu," Prisma, 8, no. 2 (Feb. 1979), p. 55.

131. Ibid.

132. Marbangun Hardjowirogo, "Pengaruh Feodalistis Bahasa dan Kebudayaan Jawa," Sinar Harapan, May 11, 1977, p. 5.

133. M. Wonohito, "Kudu Lali Basa Jawa," Mekar Sari, 15, no. 1 (March 1, 1971).

134. Bisri Adisoedarmo, "Nalusuri Kasusastran Jawi."

135. See Far Eastern Economic Review, Sept. 25, 1981, p. 102. 
sense of the word. The themes of nationalist or revolutionary struggle and of problems relating to economic development as it is defined at the national level appear recurrently. ${ }^{136}$ In Javanese magazines considerable coverage is given to national events and the capital's politics. It is not inconsistent with nationalism to report these events in Javanese, for Indonesia's Constitution explicitly affirms the importance of regional languages and guarantees them the right of existence.

It is almost unnecessary to add that scarcely any of those who have argued so vociferously that Javanese is feudal in character have addressed the question of whether a language can embody a particular ideology in its structure in such a way that any speaker of that language must, willy-nilly, speak the ideology. To my knowledge the only serious attempt to grapple with this question has come from Professor Benedict Anderson of Cornell University, who, in recent times has become something of a proponent of the view that the Javanese have failed to produce a contemporary literature in their own language. In a recent unpublished paper Anderson argues that in the twentieth century, and especially since Indonesia's independence, Javanese literature has turned into a kind of ghostly absence. He attributes the appearance of what he calls this "black hole" in Javanese literary life to three factors. First, he claims, the Javanese language was not equal to the demands of a large, modern, multiethnic polity dominated by cities and printcapitalism. Then, because of its restricted area of currency and its difficulty, it lost out as a candidate for the national language of Indonesia to the more widely spread and more easily learned Malay language. Finally, and for Anderson most importantly, Javanese society was beset with internal difficulties relating to its language and literature, which drove serious or great writers to distance themselves from the vernacular of their mother culture and express themselves in the more culturally unencumbered medium of Indonesian. In essence, Anderson argues that, because of the presence of rigidly entrenched honorific levels in Javanese which are not separate "languages" tied to certain social groups but suffuse the speech of almost all social groups, the language is irredeemably feudal in character, it has "menacing socio-cultural implications," and cannot be used by writers seeking to examine their culture in any kind of critical or irreverent way. ${ }^{137}$ Although Anderson somewhat grudgingly acknowledges that there has been "a steady, if not voluminous, stream of Javanese-language poetry, short stories, novels and other writings," he asks "how many people believe that these works are either of abiding quality or seriously engage the attention of Javanese society." 138

136. See for example the novels Lara Larane Kaum Republik (1967) and Kadurakan Ing Kidul Dringu (1964) by Suparto Brata (on the Revolution), and Tunggak-Tunggak Jati (1977) by Esmiet and Tumbaling Kreteg Somaulun (1977) by Soedharmo K.D. (on rural development).

137. Anderson, "Sembah-Sumpah."

138. Ibid., p. 2, n. 3. Anderson's words almost exactly echo the sentiments expressed by Pigeaud fifty years ago, that contemporary writing "cannot be regarded as a factor of any importance in the social and literary renewal of the Javanese"; see $n$. 31 above. If contemporary writing is so irrelevant, one wonders how it managed to traverse the last half century and still retain a spark of vitality. Curiously, Anderson asserts that, in contrast to Javanese literature, Sundanese literature seems to have survived, ibid., pp. 3 and 41. Sundanese literature has indeed "survived," and the plain fact of the matter is that Javanese literature is just as alive as Sundanese literature is. In fact, if magazine circulations are any guide (and I believe they are as good a guide as any to the popular currency of factual and imaginative writing), Javanese writing is in a somewhat healthier state. The 
Anderson's question is, of course, put rhetorically, for if he were to put it in actuality anywhere in Central and East Java outside the avant-garde and traditionalist elites, especially to moderately educated farmers and officials in country areas, he would more than likely hear an answer that would entirely demolish the "black hole" thesis. But the most telling way of rebutting Anderson's argument is to point to examples in contemporary Javanese writing of skepticism and satire directed against Javanese society. Conveniently, Anderson's own work provides a beginning point for such a rebuttal. In 1978 he published an English translation of a collection of satirical stories in Indonesian, M.M.M. dan Lain-Lain Ceritera Binatang Modern. ${ }^{139}$ Anderson rightly praises the deft satire of the stories and observes that much of their vitality springs from an "effervescent stream of social criticism and satire [which has] remained confined to private life" and which embraces a Javanese "pride in imaginative word-play" and the "patter of punakawan [clowns] in the wayang." 140 Overlooking Javanese-language sources, Anderson fails to notice that, two years before the Indonesian stories appeared, Prijana published a very similar collection of tales in Javanese under the title Dongeng Sato Kewan [Animal Fables]. To my mind, the Javanese stories are not one whit less biting in their impact than those written later in Indonesian, and in their populist, satirical, thoroughly antielitist character bear eloquent testimony to the capacity of modern Javanese to be a vehicle for critical discussion of Javanese society. ${ }^{141}$ It would not be true to say that contemporary Javanese literature as a whole is radical in the way Prijana's stories are--quite the contrary in fact. But it is clear from Prijana's work (and he is by no means the only Javanese writer to have essayed criticism of his society) that the reasion for the fairly conservative character of most social comment in Javanese is not to be sought in the structure or character of the language. ${ }^{142}$

principal vehicle for new writing in Sundanese, the magazine Mangle, presently has a circulation of around 10,000 . See Tempo, November $20,1982, \mathrm{p} .55$. This scarcely compares favorably with the circulations of Panjebar Semangat, Jaya Baya, and Djaka Lodang, currently the main vehicles of literary expression in Javanese.

139. Ben Anderson, "M.M.M.: Five Animal Tales by Pak Prijana Winduwinata," Indonesia, 25 (April 1978), pp. 81-114.

140. Ibid., p. 81.

141. Prijana Winduwinata, Dongeng Sato Kewan (Jakarta: Balai Pustaka, 1952). In these, Prijana cleverly manages to equate the traditional, feudal Javanese political and social order with that of the modern Indonesian state, thereby making his satire doubly barbed. His humor is very characteristically Javanese. Who could forget, for example, his hilarious portrait of a speechifying politician (a monkey in the story), who becomes so carried away with his gestures that his audience (who, typically are not really listening to him) thinks he is demonstrating a new dance and break into a burbled and hummed "gamelan" accompaniment [gamelan cangkem], see $\mathrm{pp}$. 25-26. The collection is very interesting for the use it makes of Indonesian words and phrases. For example, where officials or politicians attempt to hoodwink the public or use the authority of officialese and "high" language to justify their excesses or hide their corruption, Indonesian (sometimes English and Dutch) words and phrases appear. The phrase "for the benefit of the country," to cite one example, spoken by bloated officials from the land of bedbugs, is always given in Indonesian [untuk kepentingan negara]. In places Prijana skillfully uses Indonesianized Javanese to devalue the bombast of political rhetoric. How different the revolutionary cry "Merdeka!" becomes when it is bellowed out in its ironic Javanese translation "Jaya!"

142. Edward Said remarks, more than a little scathingly, on the Orientalist "truth" 
The national culture of Indonesia is an elite culture. It is city-centered and backed by central government authority, money, and institutions. Publishing houses, printers, cultural centers, theaters, bookshops, libraries, schools, and universities--with few exceptions, all are dominated by the national culture, all are located in the major cities, and all are difficult of access to the majority of those interested in contemporary regional literatures. ${ }^{143}$ Javanese writers suffer from the general government neglect of rural and regional society. They cannot, for example, hope for anything like the government assistance through prizes, subsidized royalties, contracts for school readers, and so on, that writers in Indonesian can often receive. Their readers do not have strong buying power, nor are they concentrated mainly in cities in convenient proximity to bookshops and magazinedistribution points. ${ }^{144}$ Indonesia's powerful, high-status, relatively wealthy national culture has a predatory impact on Javanese writers, frequently enticing them away from commitment to their own language to wider fame and more lucrative markets in the domain of Indonesian literature, just as in other parts of the Third World writers have turned from their indigenous languages to the epochalist and material blandishments of English and French. ${ }^{145}$

Through its administrative arms the Indonesian government has tended to promote the national language and culture at the expense of regional languages and cultures. The Newspapers in Villages [Koran Masuk Desa] campaign, conceived by the Department of Information, upset journalists on Javanese-language magazines and newspapers in its early days, because it initially failed to acknowledge the already considerable role of these publications in the rural life of Java, let alone

that Arabic as a language is a dangerous ideology, and concludes "where then does Arabic influence the Arabic mind? Exclusively within the mythological world created for the Arab by Orientalism." See Said, Orientalism, p. 320.

143. The Sasono Mulyo cultural center, run by the Central Java provincial government's Central Java Cultural Center [Pusat Kebudayaan Jawa Tengah] in Solo, is a notable exception here. Literary discussions have been held at the center, and it has helped with Javanese publications and literary competitions.

144. See Soedharma, "Sastra dan Pengarangnya," pp. 2-3, and Arswendo Atmowiloto, "Kalaupun Sastra Jawa Berakhir, Apa Salahnya?" Pesta Tulisan (Yogyakarta: Pabrik Tulisan, 1977).

145. Anie Sumarno's poem "Pisambat" (see above $n, 127$ ) calls on Javanese writers not to forsake Javanese for the bigger royalties of Jakarta. One's soul, he says, needs refined spiritual nourishment [jiwa kudu klebon alusing rasa]. See also Arswendo, "Kalaupun Sastra Jawa Berakhir." It is interesting to note how the strength of nationalist ideology seems to predispose some observers, especially those sympathetic to a strictly monolingual definition of Indonesia's linguistic nationalism, to assume that writers shift from the regional languages to Indonesian either because of some clear advantage in Indonesian or because of a disadvantage associated with the regional language. Who has ever asked whether any writers have switched (or retreated) from Javanese to Indonesian because they failed to master the subtleties of Javanese, or because they found literary communication with an audience of primarily rural readers difficult or distasteful? And who has ever asked why some writers, possessing mastery of both Indonesian and Javanese, have chosen to write solely in Javanese? One name which springs to mind immediately in this connection is that of the prolific Poerwadhie Atmodhihardjo, in my estimation unquestionably one of the best writers of prose fiction Indonesia has produced since independence, yet who has never to my knowledge written imaginative literature in Indonesian. 
offer the financial support that large Indonesian-language papers received for their village editions. The Department of Education and Culture, through the Language Center, has sponsored conferences on regional languages and literature, but has been very slow to act in support of demands for a strengthening of regional languages in school programs. This has led to the suspicion that the department's conferences have been merely a ruse to placate the proponents of regional languages, while withholding more tangible support for the same languages in schools. ${ }^{146}$

Nationalist ideas of modernity and unity have also exercised an inhibiting effect on scholarly interest in regional languages and literatures. Literary critic M. S. Hutagalung remarks that regional literatures are looked down upon, and interest in regional literatures and cultures is often regarded as proof of hatred for the national literature and culture. ${ }^{147}$ The same point is made by many other critics, ${ }^{148}$ and clearly awareness of possible hostile reaction has dampened research. Fortunately this situation is now changing for the better, but in the not-too-distant past it produced a frequently apologetic tone in the commentaries of the few who did write about regional literatures at the national level. Surveying research in regional languages and literatures, Lukman Ali, a senior official of the Government Center for Language Promotion and Development (Pusat Pembinaan dan Pengembangan Bahasa) begins by saying:

There are people who, in discussing the study and development of regional languages and literatures, are extremely cautious in what they say. They are cautious because they know that they may be subjected to politically inspired accusations that they are seeking to revive narrow, regional sentiment and chauvinism which might undermine Indonesia's hard-won unity. ${ }^{149}$

He then distances himself from any such allegation by suggesting that suspicion of interest in regional languages and literatures is understandable, because of the various regional rebellions in the 1950 s and because the Dutch used research in Indonesia's regional cultures to divide the nation and perpetuate their rule. He goes on to justify research in regional languages and literatures in nationalistic terms, that is, not on the grounds of any intrinsic merit such research might have, but because it is desirable within the context of the national culture, in order to promote mutual respect among Indonesians of different cultural backgrounds. 150

In the particular case of Javanese language and literature, the overbearing impact of the national language and literature is nowhere more sharply etched than in the realm of literary criticism. A struggle seems to be taking place between two languages and two sets of critical categories. While criticism in Javanese-language periodicals is, of course, in Javanese, Indonesian tends to be very much the dominant idiom in conferences and seminars, and the few major critical studies of contemporary Javanese literature which have appeared to date have all been in Indonesian. The danger that discussion of contemporary Javanese writing will be appro-

146. See Ajip Rosidi, "Kebudayaan Daerah dan Keindonesiaan," Prisma, 8, no. 2 (Feb. 1979), p. 53; Th. Koendjono, "Kebijaksanaan Pemerintah Lain Dengan CitaCita Seminar," Kompas, Nov. 3, 1975; and Eko S., "Nyemak Seratan Seminar Pengajaran Basa Daerah," Jaya Baya, 28, no. 14 (Dec. 2, 1973), p. 6.

147. M. S. Hutagalung, "Peranan dan Kedudukan Sastra Daerah," Horison, 13, no. 10 (Oct. 1978), p. 293.

148. See, for example, Ajip Rosidi, "Kebudayaan Daerah," pp. 50-51.

149. Lukman Ali, "Kegiatan Penelitian," Bahasa dan Kesusastraan, 4 (1971), p. 25.

150. Ibid. 
priated by a "foreign" idiom, thereby predisposing critics to discuss Javanese writing in terms of writing in Indonesian, is already, unfortunately, all too evident. Some critics accord a kind of primacy to modern Indonesian literature in the study of Javanese literature, and even view Javanese writing as a mere imitative shadow of Indonesian writing, without a clear internal logic and dynamic of its own. Critic Subalidinata, for example, prefaces a survey of contemporary Javanese poetry with the comment:

Today, the national language and the regional languages exist in tandem. I can make this assertion because clearly Indonesian is at the forefront and has higher status. The regional languages follow along behind, or are used only in a limited way. ${ }^{151}$

Subalidinata then proceeds to categorize Javanese poets as "Pujangga Baru" or "Angkatan 45" in spirit. According to Suripan Sadi Hutomo, Javanese novels of the 1950 s can be equated with Indonesian novels of the Balai Pustaka period, ${ }^{152}$ and 'Tera' ( $p$ seudonym of Suparto Brata) analyzes the themes of Javanese fiction in terms of the thematic categories conventionally applied to Indonesian fiction. ${ }^{153}$ And, most significantly, nowhere has any observer of contemporary Javanese writing taken up the question of the comparative aesthetics of Indonesian and Javanese writing. It seems to be assumed that whatever aesthetic norms apply in Indonesian literature apply also in Javanese literature, and that critical categories developed for Indonesian literature can be applied without modification to Javanese literature as well. The possibility that Javanese literature might have a distinct character in more ways than simply being written in a different language, seems to have been pushed aside by the power and status of the national literature and its body of criticism.

V. "We investigate the silence, for it is the silence

that is doing the speaking."--Pierre Macherey,

A Theory of Literary Production

In recent years the study of Indonesian literatures, especially literature in the Indonesian language, has been enriched by sociological studies. But while critics have begun to talk about the sociology of literature, few, if any, have asked about the sociology of literary criticism or about the sociology of knowledge in general. For to do so would, no doubt, threaten the sense of privilege enjoyed by the critical establishment. It would call into question the critic's autonomy and thereby imperil the validity of what is perceived as the special, personal insightfulness which is conventionally taken to be the foundation of the critic's authority.

In his sprawling but vastly stimulating study Orientalism, Edward Said refers to the liberal-humanist conception of scholarship as it is known in the contemporary West--that it should be and can be "non-political, that is, scholarly, academic, impartial, above partisan or small-minded belief." But, says Said,

No one has ever devised a method for detaching the scholar from the circumstances of life, from the fact of his involvement (conscious or unconscious)

151. R. S. Subalidinata, "Puisi Moderen Dalam Kesastraan Jawa," Buletin Fakultas Sastra dan Kebudayaan Universitas Gadjah Mada, 4 (1971), p. 100. See also Arswendo, "Kalaupun Sastra Jawa Berakhir."

152. Suripan Sadi Hutomo, Telaah Kesusastraan Jawa Modern, p. 59.

153. 'Tera,' "Pamilihan Tema," pp. 23-24. See also Koendjono, "Kebidjaksanaan Pemerintah Lain." 
with a class, a set of beliefs, a social position, or from the mere activity of being a member of society. ${ }^{154}$

With a primary debt to Foucault, Said suggests that "the general liberal consensus that 'true' knowledge is fundamentally non-political obscures the highly, if obscurely, organized political circumstances obtaining when knowledge is produced." 155

In Orientalism Said documents, with massive overkill, the link between Orientalist scholarship and the ideology of Euro-American imperialism. In a later article he goes further, and argues persuasively that scholarship, and consequently knowledge, is invariably entangled with the State and its particular interests.

. . nearly everyone producing literary or cultural studies makes no allowance in his work for the truth that all intellectual and/or cultural work occurs somewhere, at some time, in some very precisely mapped-out and permissible terrain, which is ultimately contained, if not actually regulated by the State. ${ }^{156}$

Culture, cultural formations, and intellectuals, says Said, "are made possible by virtue of a very interesting network of relationships, with the State's commanding almost absolute power." Authority in scholarship, as in the arts and in other fields, is ultimately derived, he argues, from the power and presence of the State. ${ }^{157}$

Putting aside the polemical hyperbole with which Said clothes his views, what he says is apposite here, because, although I cannot set out his arguments at length, they point, I believe, to what is common in the three strands of criticism I have been discussing. In essence, the Dutch, conservative priyayi, and nationalist dismissal of contemporary Javanese writing has been an endeavor on behalf of a State, or more accurately, three variants of a State, remarkably similar in the structure of their authority. Vitality in contemporary Javanese writing does not fit into "reality" as it is constructed in the ideologies of this State; therefore it is simply not seen, or, if it is seen, it is perceived as a threat.

Dutch philological scholarship was threatened (to put it crudely but not, I think, inaccurately) by any hint of contemporary vitality in Javanese writing, because its project was to create a Dutch-controlled definition of the Javanese through the construction of a Javanese identity rooted in the past. Dutch scholarship dismissed or "didn't see" contemporary, indigenous Javanese images of themselves and their past. It created for the Javanese a new past, one to which access was only possible through the portals of Orientalist scholarship, ultimately dedicated, directly and indirectly, clearly and obscurely, to the maintenance of imperial power. The picture of Javanese culture thus created came to exhibit the classic Orientalist contradiction--Javanese culture had to be made to appear both glorious and inglorious. It had to be glorious to justify scholarly attention and, especially, to add authority to what the State, through scholarship, produced about it. But its glory was all in the past and, if the image was to be used as an instrument of control, the Javanese present had to be rendered as feeble, decadent, and inglorious as the past

154. Said, Orientalism, p. 10.

155. Ibid.

156. Edward W. Said, "Reflections on Recent American 'Left' Literary Criticism," in The Question of Textuality: Strategies of Reading in Contemporary American Criticism, ed. William V. Spanos, Paul A. Bove, and Daniel O'Hara (Bloomington: Indiana University Press, 1982), p. 21.

157. Ibid. 
(especially the distant past) had been vital and brilliant. In short, the idea of a decadent Javanese present was essential to the Dutch moral justification of their rule, and to the particular organization of power and politics which they instituted.

In somewhat analogous fashion, conservative priyayi seized upon the records and memory of a time just antecedent to the beginnings of their decline from administrative grace and lent it a glory which was deliberately contrasted with a culturally squalid present. Their intention was to keep alive a notion of the State dominated by centralized political power and an inherited hierarchy of authority in which their own interests were well entrenched.

Nationalist ideologues have been equally involved in the creation of a contrast between the Javanese past and its present, but the products of their efforts have been more contradictory, to say the least. They have found themselves caught between the desire to capitalize on images of glory in the Javanese past, and the fear of Javanese chauvinism in the present. Consequently, Majapahit and Dipanegara have become prize exhibits in the gallery of the national ideology, but at the same time the Javanese past is depicted as feudal and static, and this image, picked up and used to characterize present-day Javanese society, has become an instrument to quell resistance, perceived or real, to the propagation of the nationalist ideology of the multiethnic, unitary state with its political order and national language.

It seems to me that, in the eyes of certain authoritative observers, Javanese literature has come to possess a "permanent" form, in the sense that scholarship has given it a certain stability of form and dimension, a certain orthodoxy. This orthodoxy has been invested with authority derived from its makers, and it has remained functionally stable within the structures of which scholarship and its alter ego, politics, are part. And developments outside the received frame have become, to those whose thinking is located within it, largely invisible, or, at best, threatening.

Javanese literature still possesses a present. It is a present which rejects the rigidity and blandness of linguistic homogeneity in the nation's literary life. Irrespective of what its future may be, this present already has a significant lesson to teach all students and practitioners of the literary arts in Indonesia. Javanese writers have, at the very least, confronted the fundamental question raised by modern writing in Indonesia, that is, the question of how to create a modern literature which takes up the problems of the country's masses in an idiom immediately intelligible and credible to those masses. This is a question which writers in the national language, through their choice of language if not by personal or ideological preference, have steered away from. From the point of view of most Indonesians, the Indonesian language is still an elite language, and its literature is determinedly urban middle-class in character. When Javanese writers claim, as they frequently and justifiably do, that their writing "memasyarakat," meaning that it is directly and easily communicative to ordinary people at the rice-roots level, they are pointing to a fundamental strength in their work which literature in Indonesian has yet to develop in any really convincing form. 